\title{
60-year record of stem xylem anatomy and related hydraulic modification under increased summer drought in ring- and diffuse-porous temperate broad-leaved tree species
}

\author{
Jorma Zimmermann ${ }^{1} \cdot$ Roman M. Link ${ }^{2} \cdot$ Markus Hauck $^{1,3} \cdot$ Christoph Leuschner $^{1} \cdot$ Bernhard Schuldt $^{1,2}$ (D)
}

Received: 7 June 2019 / Accepted: 27 December 2020 / Published online: 22 February 2021

(c) The Author(s) 2021

\begin{abstract}
Key message By combining dendrochronological time-series analysis with radial vessel features, we show that the reconstruction of hydraulic properties improves our understanding of tree species' acclimation potential to climate change.

Abstract The vascular architecture plays a crucial role in the productivity and drought tolerance of broadleaf trees, but it is not yet fully understood how the hydraulic system is acclimating to a warmer and drier climate. Because vessel features may record temporal and spatial variability in climatic signals of the past better than tree-ring width, we combined dendrochronological time-series analysis with the calculation of stem hydraulic properties derived from radial vessel features. We aimed to reconstruct the development and sensitivity of the hydraulic system over six decades and to identify climatic control of xylem anatomy for five co-existing broad-leaved diffuse- and ring-porous tree species (genera Acer, Fagus, Fraxinus and Quercus) across three sites covering a precipitation gradient from 548 to $793 \mathrm{~mm}$. We observed a significant influence of the climatic water balance (CWB) on the vessel features of all species, but the time lag, magnitude and direction of the response was highly species-specific. All diffuse-porous species suffered a decline in vessel diameter in dry years, and increase in vessel density in dry years and the year following. However, F. sylvatica was the only species with a significant long-term change in anatomical traits and a significant reduction in potential hydraulic conductivity $\left(K_{\mathrm{p}}\right)$ after dry winters and in dry summers, accompanied with the largest long-term decline in tree-ring width and the largest growth reduction in and after years with a more negative CWB. In contrast, the comparison across the precipitation gradient did not reveal any significant vessel-climate relationships. Our results revealed considerable plasticity in the hydraulic system especially of $F$. sylvatica, but also evidence of the drought-sensitivity of this species in accordance with earlier dendroecological and physiological studies. We conclude that the long-term reconstruction of hydraulic properties can add substantially to the understanding of the acclimation potential of different tree species to climate change.
\end{abstract}

Keywords Climate change $\cdot$ Dendrochronology $\cdot$ Drought adaptation $\cdot$ Fagus sylvatica $\cdot$ Potential hydraulic conductivity Hydraulic plasticity $\cdot$ Vessel diameter $\cdot$ Wood anatomy $\cdot$ Wood porosity

Communicated by A. McElrone.

Christoph Leuschner and Bernhard Schuldt: Shared senior authorship.

Christoph Leuschner

cleusch@gwdg.de

1 Plant Ecology, Albrecht von Haller Institute for Plant Sciences, University of Goettingen, Untere Karspüle 2, 37073 Göttingen, Germany
2 Chair of Ecophysiology and Vegetation Ecology, Julius-Von-Sachs-Institute of Biological Sciences, University of Würzburg, Julius-von-Sachs-Platz 3, 97082 Würzburg, Germany

3 Chair of Applied Vegetation Ecology, University of Freiburg, Tennenbacher Str. 4, 79106 Freiburg, Germany 


\section{Introduction}

Drought is a key factor limiting tree vitality and growth in many regions of the temperate zone (Allen et al. 2010). Climate models for Central Europe predict a decrease in mean summer precipitation and an increasing frequency and severity of extreme drought periods (Schär et al. 2004; Trenberth et al. 2014; Zscheischler and Seneviratne 2017; Samaniego et al. 2018). A crucial role for tree performance is played by the water transport system from roots to leaves (Brodribb 2009). Under conditions of ample water supply, highly conductive xylem is a prerequisite for high photosynthetic rates (Tyree 2003; Hajek et al. 2014; Kotowska et al. 2015). In periods of drought, on the other hand, the hydraulic system needs to be resistant against hydraulic failure to maintain a positive carbon balance (McDowell 2011). A decline in soil water availability commonly favors the formation of smaller xylem vessels and higher vessel densities (Carlquist 1977; DeMicco et al. 2008; Schreiber et al. 2015), which is often accompanied by an increased xylem resistance against drought-induced hydraulic failure (Schuldt et al. 2016; Lübbe et al. 2017). Along water availability gradients, such structural modifications may counteract the increase in drought exposure and guarantee sufficient water supply to the canopy (Gleason et al. 2012, 2013). At a given site, the tree individual has experienced variable climatic conditions during its lifetime, which may imprint on wood anatomy and tree ring width (Fonti et al. 2010; Sass-Klaassen et al. 2016). Because vessel properties are closely related to water transport efficiency, wood anatomical data might provide better climatic signals than ring width data (Campelo et al. 2010; Novak et al. 2013; Rita et al. 2016). Owing to the obvious threats imposed on forestry by a future drier climate, a better understanding of spatial and temporal xylem plasticity of broad-leaved trees to environmental change is urgently needed (Fonti and Jansen 2012).

In Central Europe, European beech (Fagus sylvatica) is the most abundant broad-leaved tree species that would naturally cover two-third of Germany's land cover (Bohn et al. 2003). Dendrochronological studies and forest inventory data indicate that $F$. sylvatica is facing a climate warmingrelated growth decline in various regions of its distribution range (Jump et al. 2006; Piovesan et al. 2008; Charru et al. 2010; Scharnweber et al. 2011; Zimmermann et al. 2015; Dulamsuren et al. 2017; Knutzen et al. 2017). Several studies indicate that drought-induced growth decline can be an early sign of a higher risk of tree mortality (Bigler et al. 2006; Cailleret et al. 2017; Timofeeva et al. 2017). Affected trees often have a legacy of reduced vigor triggered by previous drought events that may cause reductions in hydraulic capacity and thus carbohydrate availability (Trugman et al. 2018). Various physiological and dendrochronological studies have characterized $F$. sylvatica as a drought-sensitive species, which shows sensitive reductions in water consumption and radial stem growth during dry episodes (e.g. Rennenberg et al. 2004; Köcher et al. 2009; Leuschner 2009), and increased mortality rates after severe drought events (Schindler 1951; Wagenhoff and Wagenhoff 1975; Schuldt et al., 2020). On the other hand, it is also regarded as a highly adaptive tree species that is able to respond with anatomical and physiological modifications to stress events (Bolte et al. 2007; Rose et al. 2009; Kramer et al. 2010; Schuldt et al. 2016). In F. sylvatica, quite a number of studies have investigated drought and heat stress effects on photosynthesis, premature leaf senescence, drought-induced reductions in radial stem growth and increased fine root mortality (Dreyer 1997; Leuschner et al. 2001; Bréda et al. 2006; Piovesan et al. 2008; Zimmermann et al. 2015). The plasticity of the xylem hydraulic system, on the other hand, has been studied much less. Available data indicate a certain plasticity in the hydraulic system of $F$. sylvatica to changing environmental conditions (Wortemann et al. 2011; Schuldt et al. 2016; Lübbe et al. 2017; Stojnić et al. 2018). However, it remains unclear whether this plasticity is sufficient to acclimate to increasing summer drought in recent time.

With progressive climate warming, the drought-sensitivity of $F$. sylvatica could in the future lead to a shift in tree species composition in mixed forests currently dominated by this species (Lindner et al. 2010; Cavin et al. 2013). Due to the great importance of beech in the natural and production forests of Europe, there is an urgent need to compare the drought response of $F$. sylvatica with that of other major and minor broad-leaved timber species, which compete with beech and could perhaps play a more prominent role in future forestry. Until now, only very few studies have investigated the temporal and spatial variation in xylem anatomical and derived hydraulic properties of co-existing temperate diffuse- and ring-porous tree species (Anderegg and Meinzer 2015). For the present study, we selected five temperate broad-leaved tree species that differ in drought sensitivity, successional status and occurrence in Central Europe. We investigated three mixed forests in which $F$. sylvatica co-occurs with Sycamore maple (Acer pseudoplatanus L.), Norway maple (Acer platanoides L.), sessile oak (Quercus petraea (Matt.) Liebl.), and common ash (Fraxinus excelsior L.). A. pseudoplatanus is a common secondary tree species in the more oceanic regions of Central Europe that, like $F$. sylvatica, requires a better water supply and higher atmospheric moisture, while the other three species $(A$. platanoides, $Q$. petraea and $F$. excelsior) are thought to be rather drought-tolerant (Roloff and Schütt 2006; Leuschner and Ellenberg 2017).

We adopted two complementary approaches for studying the hydraulic plasticity in response to water shortage in mature trees of the five tree species. Based on 60-yrlong time series derived from increment cores, we firstly 
analyzed how the wood anatomical properties of the stem xylem change in response to a period of significant warming and increasing climatic aridity, and secondly how they differ between stands distributed along a precipitation gradient. Our main research questions were to (1) quantify the degree of plasticity of the stem hydraulic system (precipitation-gradient study), (2) search for long-term trends in the hydraulic properties (time-series analysis), and (3) compare ring- and diffuse-porous species with respect to their plastic response in anatomical properties to decreasing rainfall. We tested the hypotheses that (i) the studied species adjust their xylem anatomy to a drier and warmer climate by producing smaller vessels, (ii) drought-sensitive $F$. sylvatica shows the most pronounced vessel diameter reduction, and (iii) radial vessel features provide a more informative climatic signal than tree-ring width data alone.

\section{Material and methods}

\section{Study area and sampled stands}

The study took place in central Germany in three mixed forests along a precipitation gradient from 793 to $548 \mathrm{~mm}$ year $^{-1}$ in the transition zone between a sub-oceanic climate in the west and a more sub-continental climate in the east (Table 1). The three forests are located at $250-450 \mathrm{~m}$ elevation between the villages of Keula and Wettelrode in the lee of the Harz Mountains (south-western Saxony-Anhalt and northern Thuringia) in close proximity to each other (west-east extension of $50 \mathrm{~km}$ only). The study region is thought to be close to the drought limit of $F$. sylvatica and A. pseudoplatanus in Central Europe, while A. platanoides, $Q$. petraea and $F$. excelsior likely tolerate drier climates (Leuschner and Ellenberg 2017). The three stands are situated in the assumed transition zone between beech-dominated forests in a moister sub-oceanic climate (stand 1) to mixed forests with higher abundance of Quercus, Acer, Tilia, Fraxinus and Carpinus species under a more summer-dry sub-continental climate (stands 2 and 3, Table 1). The three selected diffuse-porous species $F$. sylvatica, A. pseudoplatanus and A. platanoides and the two ring-porous species $Q$. petraea and F. excelsior vary largely in wood anatomical traits (Fig. 1) and assumed drought-response strategies (Roloff and Schütt 2006; Köcher et al. 2009).

The study region is characterized by small-scale variation in geological substrates (VFS 2005); two of the stands are located on Triassic limestone, one on pellite rock (for further details see Zimmermann et al. 2015). All studied trees had an age of $\sim 100$ year and a diameter at breast height (DBH) mostly in the range of $40-55 \mathrm{~cm}$; exceptions were older and thicker oak trees in stand 1 (Table 1). All stands grew on north-facing slopes with a higher inclination in stand 2 $\left(20^{\circ}-30^{\circ}\right)$ than in stand 1 and $3\left(5^{\circ}-10^{\circ}\right)$. Stand 2 stocked on a mosaic of limestone and igneous rocks with variable soil depth; beech typically grew on the shallower and oak on the deeper soils.

\section{Climate data}

While weather stations recording precipitation were available in the neighborhood of all three stands, temperature
Table 1 Stand and microclimatic characteristics of the three investigated forest stands in Central Germany

\begin{tabular}{|c|c|c|c|c|c|}
\hline Variable & Unit & Observation period & $\begin{array}{l}\text { Stand } 1 \\
\text { Hainleite }\end{array}$ & $\begin{array}{l}\text { Stand } 2 \\
\text { Großleinungen }\end{array}$ & $\begin{array}{l}\text { Stand } 3 \\
\text { Roßla }\end{array}$ \\
\hline Coordinates & & & $51^{\circ} 23^{\prime} \mathrm{N} 10^{\circ} 44^{\prime} \mathrm{E}$ & $51^{\circ} 30^{\prime} \mathrm{N} 11^{\circ} 13^{\prime} \mathrm{E}$ & $51^{\circ} 29^{\prime} \mathrm{N} 11^{\circ} 04^{\prime} \mathrm{E}$ \\
\hline Elevation & $\mathrm{m}$ & & $400-450$ & $250-300$ & $300-350$ \\
\hline MAT & ${ }^{\circ} \mathrm{C}$ & Jan.-Dec & 7.61 & 8.55 & 9.04 \\
\hline MAP & $\mathrm{mm}$ & Jan.-Dec & 793.23 & 589.60 & 548.33 \\
\hline VPD & $\mathrm{kPa}$ & Jan.-Dec & 0.20 & 0.26 & 0.30 \\
\hline CWB & $\mathrm{mm}$ & Jan.-Dec & 153.17 & -72.48 & -113.75 \\
\hline MST & ${ }^{\circ} \mathrm{C}$ & Apr-Jun & 10.99 & 11.98 & 12.55 \\
\hline MSP & $\mathrm{mm}$ & Apr.-Jun & 183.77 & 154.57 & 146.60 \\
\hline $\mathrm{VPD}_{\text {gro }}$ & $\mathrm{kPa}$ & Apr.-Jun & 0.31 & 0.39 & 0.44 \\
\hline $\mathrm{CWB}_{\text {gro }}$ & $\mathrm{mm}$ & Apr.-Jun & -72.20 & -110.60 & -118.57 \\
\hline
\end{tabular}

Given are stand coordinates and elevation (m a.s.l.) and four climatic variables for the period from 1981 to 2010. These are mean annual temperature (MAT, ${ }^{\circ} \mathrm{C}$ ), mean annual precipitation (MAP, mm), mean annual vapor pressure deficit $(\mathrm{VPD}, \mathrm{kPa})$, and the mean annual climatic water balance, i.e. precipitation-potential evapotranspiration $(\mathrm{CWB}, \mathrm{mm})$. All four climatic variables are also given for the early growing season from April to June, i.e. mean early growing season temperature (MST, ${ }^{\circ} \mathrm{C}$ ), mean early growing season precipitation (MSP, $\mathrm{mm}$ ), mean early growing season vapor pressure deficit ( $\left.\mathrm{VPD}_{\text {gro }}, \mathrm{kPa}\right)$, and mean early growing season climatic water balance $\left(\mathrm{CWB}_{\mathrm{gro}}, \mathrm{mm}\right)$. For further details on site characteristics and soil conditions see Zimmermann et al. (2015) 

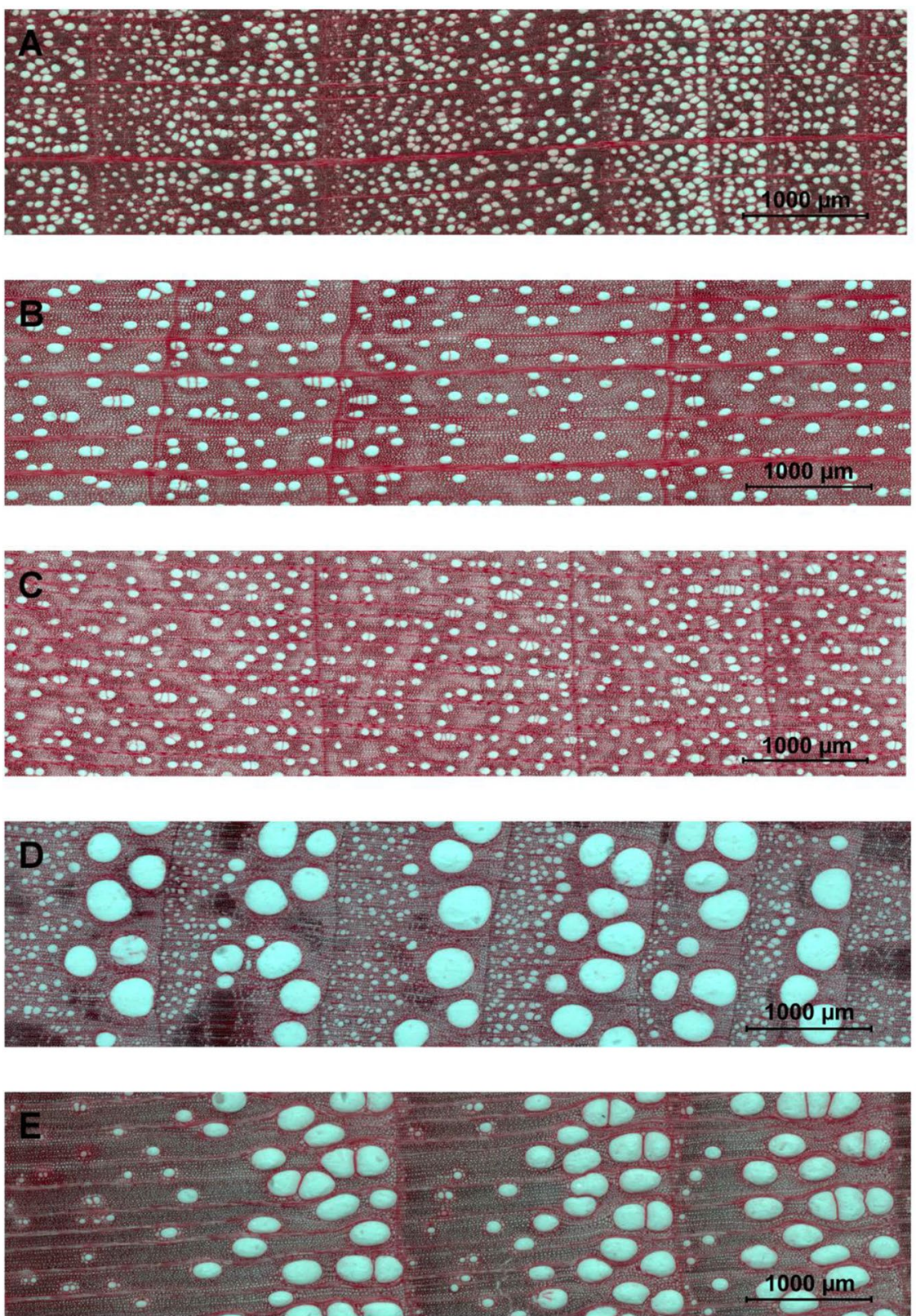
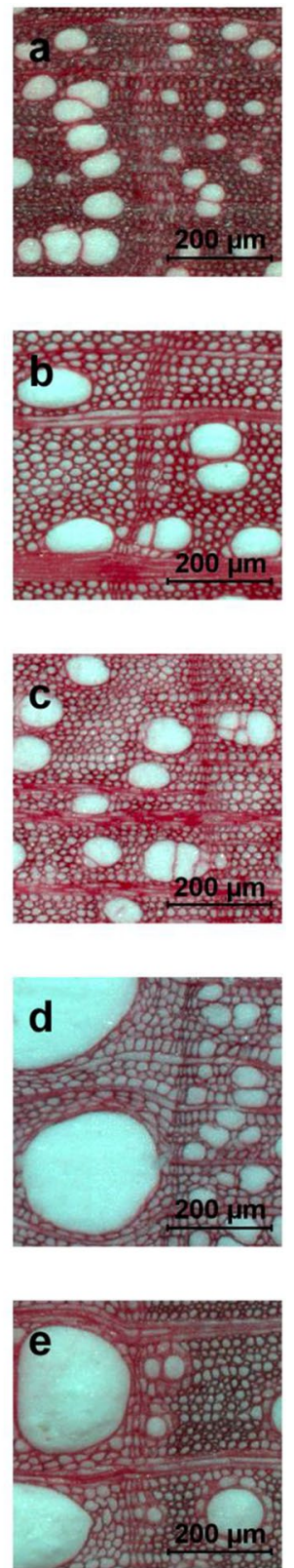

Fig. 1 Cross-sections of stem xylem of the three diffuse-porous (a-c) and two ring-porous (d, e) tree species at $\times 100$ magnification. a Fagus sylvatica, b Acer pseudoplatanus, c Acer platanoides, d Quercus petraea, e Fraxinus excelsior

was only recorded at a single station in the study region after 1954 (station Artern, 164 m a.s.1.), and the precipitation datasets contained gaps at two of the sites. For that reason, the climate variables used for this study are based on interpolated data extracted from publicly available gridded climate datasets using the above-mentioned climate data (which differs from the approach adopted earlier by Zimmermann et al. 2015). Monthly means of air temperature and monthly precipitation sums were extracted for the time interval 1951-2010 based on $1 \mathrm{~km} \times 1 \mathrm{~km}$ grids provided by the Climate Data Center (CDC) of the German Weather
Service (DWD, Deutscher Wetterdienst, Offenbach, https ://opendata.dwd.de/, accessed on Nov 14, 2019) accessed with the R package rdwd v. 1.2.0 (Boessenkool 2019). As the spatially highly resolved data provided by the CDC do not cover the entire study period from 1951 to 2010, modelbased estimates of evapotranspiration and average atmospheric vapour pressure were extracted from $0.5^{\circ} \times 0.5^{\circ}$ grids provided by the Climate Research Unit (CRU) TS 4.03 dataset (Harris et al. 2014; https://crudata.uea.ac.uk/ cru/data/hrg/cruts_4.03/, accessed on Nov 15, 2019) using the R package cruts v. 0.5 (Taylor et al. 2018). The extracted 
precipitation and evapotranspiration data were used to calculate the monthly cumulative water balance $(\mathrm{CWB}, \mathrm{mm}$ $\mathrm{mo}^{-1}$ ) as the difference between precipitation and evapotranspiration. For each point in time and every site, the saturating vapour pressure $\left(e_{\mathrm{sat}}\right)$ was derived from air temperature, and vapor pressure deficit (VPD, $\mathrm{kPa}$ ) calculated as the difference between $e_{\text {sat }}$ and actual vapor pressure according to Allen et al. (1998). For the subsequent inclusion in statistical models, the monthly averages of climate variables were aggregated on an annual basis by calculating averages (temperature, VPD) or sums (precipitation, climatic water balance) over the full year as well as for the growing season (April-October), early growing season (April-June) and winter (November-March).

\section{Wood core sampling and preparation}

For the wood anatomical measurements, five individuals of the five target tree species were sampled (one core per tree) in each of the three stands in the period July-October 2011. The trees selected for sampling belonged to the upper canopy layer, were comparable in DBH and, most importantly, in height among the species and belonged to the largest and tallest trees of the stands (Table 2). As dominant trees in the upper canopy layer, they were fully exposed to the free atmosphere and will have experienced climate change more directly than smaller tree individuals. Two cores of A. platanoides from stand 1 could not be analysed due to micro-cracks sustained during the preparation

Table 2 Structural data and number $(n)$ of sampled trees from the five tree species within the three stands

\begin{tabular}{llcccc}
\hline Species & Stand & $n$ & Age (years) & DBH $(\mathrm{cm})$ & Height $(\mathrm{m})$ \\
\hline F. sylvatica & 1 & 5 & $89 \pm 7^{\mathrm{a}}$ & $51.6 \pm 8.7^{\mathrm{ac}}$ & $31.8 \pm 1.2^{\mathrm{ab}}$ \\
& 2 & 5 & $101 \pm 20^{\mathrm{a}}$ & $52.8 \pm 5.1^{\mathrm{ac}}$ & $31.9 \pm 2.5^{\mathrm{ab}}$ \\
& 3 & 5 & $98 \pm 12^{\mathrm{a}}$ & $45.6 \pm 5.3^{\mathrm{ab}}$ & $29.6 \pm 0.9^{\mathrm{bc}}$ \\
A. pseudopla- & 1 & 5 & $100 \pm 8^{\mathrm{a}}$ & $50.1 \pm 5.0^{\mathrm{ab}}$ & $31.8 \pm 1.2^{\mathrm{ab}}$ \\
tanus & 2 & 5 & $105 \pm 25^{\mathrm{a}}$ & $53.4 \pm 5.4^{\mathrm{bc}}$ & $29.8 \pm 1.9^{\mathrm{bc}}$ \\
& 3 & 5 & $87 \pm 19^{\mathrm{a}}$ & $46.2 \pm 10.0^{\mathrm{ab}}$ & $27.7 \pm 2.8^{\mathrm{c}}$ \\
A. platanoides & 1 & 3 & $90 \pm 8^{\mathrm{a}}$ & $41.7 \pm 1.6^{\mathrm{ab}}$ & $30.2 \pm 2.9^{\mathrm{bc}}$ \\
& 2 & 5 & $101 \pm 18^{\mathrm{a}}$ & $51.6 \pm 8.5^{\mathrm{ac}}$ & $27.9 \pm 1.8^{\mathrm{cd}}$ \\
& 3 & 5 & $109 \pm 8^{\mathrm{a}}$ & $38.6 \pm 6.9^{\mathrm{a}}$ & $27.9 \pm 2.3^{\mathrm{cd}}$ \\
Q. petraea & 1 & 5 & $158 \pm 11^{\mathrm{b}}$ & $64.9 \pm 5.8^{\mathrm{c}}$ & $30.9 \pm 1.8^{\mathrm{bc}}$ \\
& 2 & 5 & $109 \pm 15^{\mathrm{a}}$ & $55.7 \pm 5.8^{\mathrm{bc}}$ & $29.6 \pm 1.4^{\mathrm{bc}}$ \\
& 3 & 5 & $110 \pm 4^{\mathrm{a}}$ & $48 \pm 5.7^{\mathrm{ab}}$ & $29.4 \pm 1.7^{\mathrm{acd}}$ \\
F. excelsior & 1 & 5 & $96 \pm 10^{\mathrm{a}}$ & $51.4 \pm 6.8^{\mathrm{ac}}$ & $32.1 \pm 1.5^{\mathrm{bd}}$ \\
& 2 & 5 & $97 \pm 16^{\mathrm{a}}$ & $52.2 \pm 3.6^{\mathrm{ac}}$ & $33.6 \pm 1.2^{\mathrm{b}}$ \\
\hline
\end{tabular}

Different small letters indicate significant differences between means with $\mathrm{p}<0.05$

Given are tree age (at breast height; years) and height (m) as well as diameter at breast height $(\mathrm{DBH}, \mathrm{cm})$. Values are means \pm SD. Different small letters indicate significant differences between means process, resulting in only three cores for this species in this stand. F. excelsior was only present in stands 1 and 3. In total, 68 wood cores were analysed. Samples were collected at breast height $(1.3 \mathrm{~m})$ with an increment borer of $5.15 \mathrm{~mm}$ inner diameter (Haglöf, Langsele, Sweden) from the position where the least influence of wood tension or compression was expected. The cores were mounted on wood strips, cut and levelled with a core microtome which can handle samples of up to $40 \mathrm{~cm}$ length (Gärtner and Nievergelt 2010). The wood was dyed with safranin and the vessels filled with chalk powder and subsequently analysed for wood anatomical properties at $100 \times$ magnification using a Stereo V20 Microscope equipped with an automatic table using the software AxioVision S64 Rel 4.9 (Carl Zeiss MicroImaging $\mathrm{GmbH}$, Göttingen, Germany). About 500 images per core were taken from different sections, each focused individually, and subsequently combined to one large image for analysis. Exemplary images are shown in Fig. 1. The contrast of the images was enhanced using the graphics editing software Photoshop CS6 (Adobe Systems Incorporated, San Jose, USA). Finally, the images were split into the annual rings to analyze anatomical properties individually for every annual ring of the 60 years from 1951 to 2010, yielding 4,080 analyzed rings in total.

\section{Analysis of vessel properties}

Vessel properties were analyzed with WinCELL software v. 2011a (Régent Instruments, Quebec, Canada). The analysis was limited to vessels with a lumen area $\geq 500 \mu \mathrm{m}^{2}$, resulting in 4,928 to 61,550 measured vessels per tree and $1,336,832$ analysed vessels in total. Given their comparatively low contribution to total hydraulic conductance, we decided to exclude smaller vessels to avoid the misclassification of tracheids. The measured parameters included the area of the tree-ring segment $\left(A, \mu \mathrm{m}^{2}\right.$; separated into earlywood- and latewood area for ring-porous species), vessel density (VD, $\left.n \mathrm{~mm}^{-2}\right)$, major $(a, \mu \mathrm{m})$ and minor $(b, \mu \mathrm{m})$ vessel radii, and vessel lumen area. The latter was used to estimate relative vessel lumen area, i.e. the lumen to sapwood area ratio $\left(A_{\text {lumen }}, \%\right)$. Idealized vessel diameters $(D$, $\mu \mathrm{m})$ were calculated according to Lewis and Boose (1995) as $D=\left(32 \times(a \times b)^{3} /\left(a^{2}+b^{2}\right)\right)^{1 / 4}$, and used to calculate hydraulically-weighted vessel diameter $D_{\mathrm{h}}(\mu \mathrm{m})$ after Sperry et al. (1994) as $D_{\mathrm{h}}=\Sigma D^{5} / \Sigma D^{4}$. The theoretical hydraulic conductivity $\left(K_{\mathrm{h}}, \mathrm{kg} \mathrm{m} \mathrm{MPa}^{-1} \mathrm{~s}^{-1}\right)$ of a tree-ring segment was calculated by adding up the conductance of all vessels as obtained from Hagen-Poiseuille's equation as $K_{\mathrm{h}}^{\text {theo }}=\pi \times \rho \times \Sigma D^{4}$ / $(128 \times \eta)$, where $\eta$ is the viscosity $\left(1.00210^{-9} \mathrm{MPa} s\right)$ and $\rho$ the density of water $\left(998.2 \mathrm{~kg} \mathrm{~m}^{-3}\right)$, both at $20^{\circ} \mathrm{C}$. The potential conductivity $\left(K_{\mathrm{p}}, \mathrm{kg} \mathrm{m}^{-1} \mathrm{MPa}^{-1} \mathrm{~s}^{-1}\right)$ was then calculated by dividing $K_{\mathrm{h}}^{\text {theo }}$ by the cross-sectional area of the corresponding tree-ring segment $\left(A, \mathrm{~m}^{2}\right)$. 


\section{Data processing and exploratory analysis}

All data handling and statistical analyses were performed in R v. 4.0.2 (R Core Team 2020) in the framework of the tidyverse package (Wickham et al. 2019). For the ringporous species, all vessel traits were analyzed separately for earlywood- and latewood vessels. To achieve this, the vessels were classified into two groups via k-means clustering based on vessel dimensions and position from the WinCell-based vessel anatomical datasets using the $\mathrm{R}$ function kmeans () . Temporal trends in climate variables were analyzed by calculating Kendall's Tau as a measure of nonlinear bivariate association for the periods from 1951 to 1980 and from 1981 to 2010 (first and second half of the study interval) followed by bootstrap tests against the null-hypothesis that there is no association. To assess how wood anatomical traits co-vary with tree ring width (TRW), stand-specific bivariate Pearson correlations between this variable, hydraulically weighted vessel diameter $\left(D_{\mathrm{h}}\right)$ and vessel density (VD) were calculated for each species. In all subsequent analyses of wood anatomical traits, early- and latewood vessels of ring-porous species were treated as separate entities due to their vastly different behaviour, resulting in a dataset of 5,580 observations of anatomical variables and 4,080 ring width observations belonging to complete 60-year time series of 68 trees.

\section{Models for wood anatomical traits and tree ring width}

To analyze how $D_{\mathrm{h}}$, VD and $K_{\mathrm{p}}$ respond to inter-annual differences in water availability as well as for separating size-related signals from long-term changes throughout the research interval, we used a mixed-effects modelling approach based on the R package glmmTMB v. 1.0.1 (Brooks et al. 2017). To separate between ontogenetic signals and long-term trends, we allowed for tree-specific diameter effects. For the wood anatomical parameters, three analogous models were set up using natural $\log$-transformed $D_{\mathrm{h}}, \mathrm{VD}$ and $K_{\mathrm{p}}$ as response variables. To analyze the immediate effect of inter-annual differences in water availability, we included species-/wood type-specific effects of cumulative water balance (CWB; precipitation-evapotranspiration) of the current growing season (April-October), the past winter (November-March), and the previous growing season. In addition, we included species-/wood type-related effects of time and DBH to account for species-/wood typespecific long-term trajectories and average size effects, and added an overall effect of stand identity to account for differences between stands. All numerical predictor variables were scaled by their standard deviations and centered to aid model convergence. As random effects, we allowed for tree-specific random intercepts $\left(u_{\text {int }}\right)$ and random slopes for DBH $\left(u_{\mathrm{DBH}}\right)$ to account for individual differences in the size response (thus effectively detrending under the assumption of a log-linear relationship between DBH and the response variable). In addition, we included random intercepts for each year $\left(v_{\text {year }}\right)$ as a crossed random effect to account for random interannual variation neither captured by the linear long term trend nor the CWB effects. The model equation for the observed wood anatomical variable $y_{\mathrm{ijkl}}$ for observation $i$ on tree $j$ of species/ wood type $k$ on stand $l$ in the year $t$ could thus be expressed as:

$$
\begin{aligned}
\log \left(y_{i j k l}\right)= & \alpha_{l}+\beta_{1[k]} \mathrm{CWB}_{\text {sum } 0[i]}+\beta_{2[k]} \mathrm{CWB}_{\operatorname{win}[i]}+\beta_{3[k]} \mathrm{CWB}_{\text {sum } 1[i]} \\
& +\beta_{4[k]} Y r_{[i]}+\left(\beta_{5[k]}+u_{\mathrm{DBH}[j]}\right) \mathrm{DBH}_{[i]}+u_{\text {int }[j]}+v_{\text {year }[t]}+\varepsilon_{i},
\end{aligned}
$$

where $\alpha_{1}$ are the site-specific fixed intercepts, $\beta_{1[\mathrm{k}]}-\beta_{5[\mathrm{k}]}$ are species-specific regression coefficients for the climatological water balance at different time lags $\left(\mathrm{CWB}_{\text {sum0[i] }}\right.$, $\mathrm{CWB}_{\text {win }[i]}$ and $\left.\mathrm{CWB}_{\text {sum } 1[i]}\right)$, the scaled and centered year $\left(\mathrm{Yr}_{i}\right)$ and the diameter at breast height $\left(\mathrm{DBH}_{i}\right)$, and $\varepsilon_{i}$ are the model residuals. Note that (a) individual age trends were described by DBH instead of the raw age to reduce the collinearity between long-term trends and individual growth trends, and (b) even if DBH was perfectly determined by age, the model would be identifiable as long as at any given point in time, trees differ in DBH.

The random year effects were assumed to be normally distributed around a mean of zero, while the random tree effects analogously were assumed to follow a multivariate normal distribution, allowing the random tree intercepts and the slopes for DBH to be correlated.

$\boldsymbol{v}_{\text {year }} \sim \operatorname{Normal}\left(0, \tau_{\text {year }}\right)$

$\left(\begin{array}{c}\boldsymbol{u}_{\text {int }} \\ \boldsymbol{u}_{\mathrm{DBH}}\end{array}\right) \sim \operatorname{MVN}\left(\left(\begin{array}{l}0 \\ 0\end{array}\right), \Sigma_{\text {tree }}\right)$.

To account for temporal autocorrelation, we included a tree-wise AR1 residual autocorrelation term, which can be expressed as a multivariate normal distribution on the model residuals with a block-diagonal AR1 correlation matrix with residual standard deviation $\sigma_{\mathrm{res}[i]}$ and autocorrelation parameter $\phi$ :

$\boldsymbol{\epsilon} \sim \operatorname{MVN}\left(0, \boldsymbol{\Sigma}_{\text {res }}\right)$,

$\boldsymbol{\Sigma}_{\mathrm{res}[m, n]}= \begin{cases}\sigma_{\text {res }[i]}^{2} & \text { if } m=n \\ \sigma_{\text {res }[i]}^{2} \phi^{2|m-n|} & \text { if } m \neq n \text { and Tree }{ }_{m}=\text { Tree }_{n} . \\ 0 & \text { otherwise }\end{cases}$

Initial analyses suggested a high degree of heterogeneity in error variances, with pronounced species/wood type differences and a clear decrease of the variance in $D_{\mathrm{h}}$, VD and $K_{\mathrm{p}}$ with the number of observed vessels in a crosssection. We therefore included an explicit variance model, expressing natural log-transformed variance as a function of 
species/wood type and the natural log-transformed number of observed vessels per analyzed cross-section:

$\ln \left(\sigma_{r e s[i]}^{2}\right)=\sigma_{i n t[l]}+\beta_{\sigma} \ln \left(n_{i}\right)$

An analogous model was fit for tree ring width, differing from the aforementioned models only in that no transformation of the response was necessary, that early- and latewood of ring-porous species were not treated separately and that the error variance was not modeled as a function of the number of observed vessels. Bootstrapped p-values and 95\% confidence intervals for the model parameters and functions thereof where computed using model-based parametric bootstrap resampling based on the bootMer () function of $R$ package lme 4 v. 1.1-23 (Bates et al. 2015). As a measure of explained variance, marginal and conditional pseudo- $R^{2}$ values were computed for the entire dataset and on species/ wood type-level based on the methods described in Nakagawa and Schielzeth (2013).
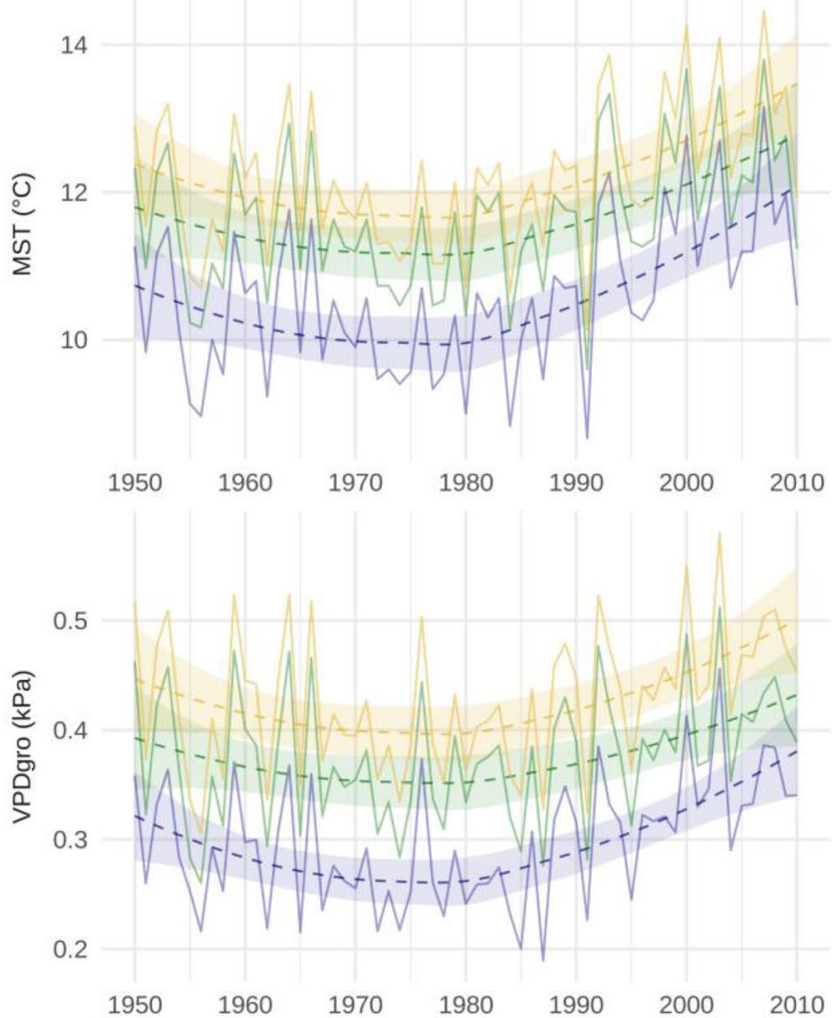

Fig. 2 Climate in the three studied forest stands over the research interval from 1951 to 2010. Shown are the mean early growing season temperature (MST), mean early growing season precipitation (MSP), vapor pressure deficit (VPD) and climatic water balance

\section{Results}

\section{Climate trends throughout the study interval}

During the first 30 years of the study interval (1951-1980), no significant changes in climate conditions could be detected in any of the research sites (Fig. 2, Table 3). In the second half of the research interval (1981-2010), there was a significant increase in average early growing season temperature of $0.55{ }^{\circ} \mathrm{C}$ per decade in all sites, while precipitation remained relatively stable, leading to an increase in VPD by on average $0.035 \mathrm{kPa}$ per decade (Fig. 2, Table 3). While the increased evaporative demand led to a slight decrease in the climatological water balance over the same interval, this change was not significant in any of the sites (Fig. 2, Table 3).

\section{Overall model performance}

The models for wood anatomical variables achieved a very high goodness of fit. Predictions based on the fixed effects
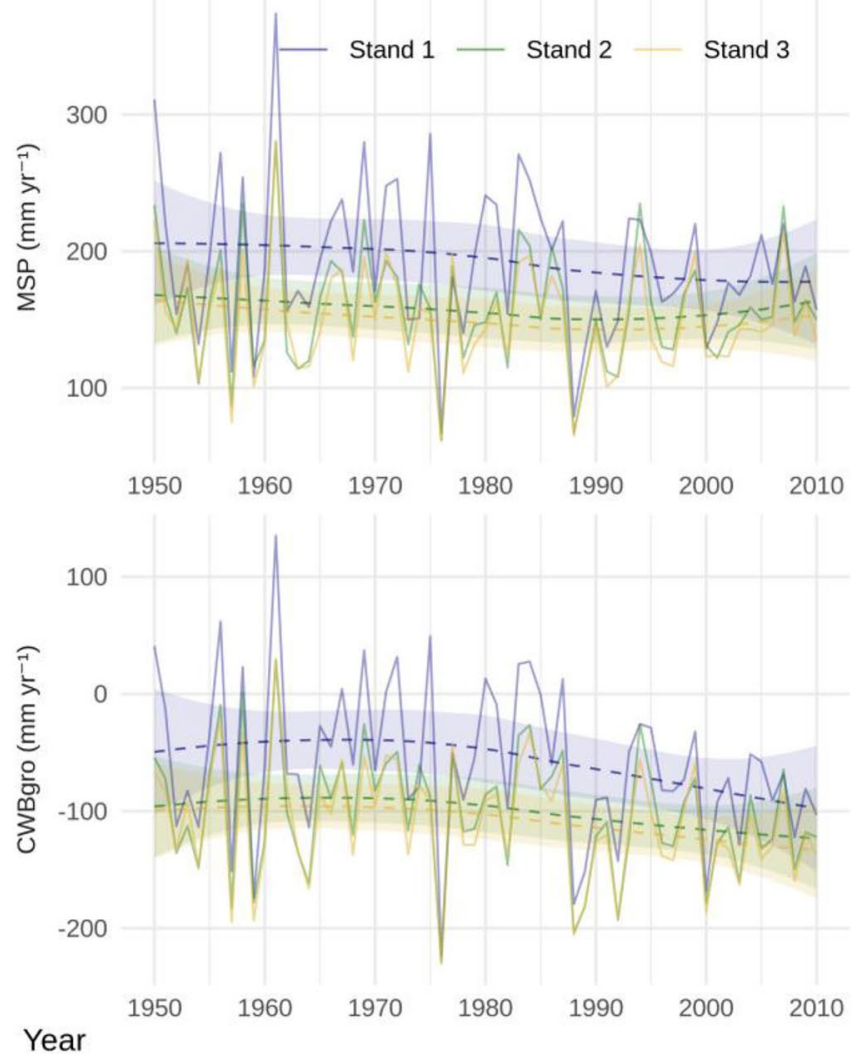

(precipitation-evapotranspiration), each for the period from April to June and overlain with a LOESS non-parametric smoothing function including its $95 \%$ confidence intervals to illustrate the overall trends 
Table 3 Non-linear temporal trends in climate variables (Kendall's Tau with $p$ values based on 10,000 bootstrap draws)

\begin{tabular}{|c|c|c|c|c|c|}
\hline \multirow[t]{2}{*}{ Variable } & \multirow[t]{2}{*}{ Stand } & \multicolumn{2}{|c|}{ 1951-1980 } & \multicolumn{2}{|c|}{$1981-2010$} \\
\hline & & $\begin{array}{l}\text { Kendall's } \\
\text { Tau }\end{array}$ & $p$ value & $\begin{array}{l}\text { Kendall's } \\
\text { Tau }\end{array}$ & $p$ value \\
\hline \multirow[t]{3}{*}{ MAT } & Stand 1 & -0.048 & 0.725 & 0.264 & $0.038^{*}$ \\
\hline & Stand 2 & -0.002 & 1.000 & 0.214 & 0.105 \\
\hline & Stand 3 & -0.034 & 0.803 & 0.223 & 0.088 \\
\hline \multirow[t]{3}{*}{ MST } & Stand 1 & -0.200 & 0.125 & 0.392 & $0.003 * *$ \\
\hline & Stand 2 & -0.190 & 0.154 & 0.277 & $0.032 *$ \\
\hline & Stand 3 & -0.215 & 0.106 & 0.331 & $0.011^{*}$ \\
\hline \multirow[t]{3}{*}{ MAP } & Stand 1 & -0.101 & 0.450 & 0.122 & 0.349 \\
\hline & Stand 2 & -0.103 & 0.436 & 0.182 & 0.170 \\
\hline & Stand 3 & -0.129 & 0.325 & 0.120 & 0.363 \\
\hline \multirow[t]{3}{*}{ MSP } & Stand 1 & 0.037 & 0.791 & -0.161 & 0.218 \\
\hline & Stand 2 & 0.000 & 1.000 & 0.023 & 0.872 \\
\hline & Stand 3 & -0.032 & 0.823 & 0.002 & 1.000 \\
\hline \multirow[t]{3}{*}{ VPD } & Stand 1 & -0.030 & 0.830 & 0.379 & $0.003 * *$ \\
\hline & Stand 2 & 0.016 & 0.912 & 0.195 & 0.136 \\
\hline & Stand 3 & -0.016 & 0.916 & 0.301 & $0.020 *$ \\
\hline \multirow[t]{3}{*}{$\mathrm{VPD}_{\text {gro }}$} & Stand 1 & -0.159 & 0.225 & 0.471 & $<0.001 * * *$ \\
\hline & Stand 2 & -0.076 & 0.574 & 0.274 & $0.037 *$ \\
\hline & Stand 3 & -0.108 & 0.418 & 0.361 & $0.005 * *$ \\
\hline \multirow[t]{3}{*}{ CWB } & Stand 1 & -0.094 & 0.481 & 0.048 & 0.718 \\
\hline & Stand 2 & -0.076 & 0.577 & 0.053 & 0.696 \\
\hline & Stand 3 & -0.131 & 0.320 & 0.034 & 0.804 \\
\hline \multirow[t]{3}{*}{$\mathrm{CWB}_{\text {gro }}$} & Stand 1 & 0.067 & 0.619 & -0.218 & 0.096 \\
\hline & Stand 2 & 0.080 & 0.540 & -0.149 & 0.248 \\
\hline & Stand 3 & 0.009 & 0.954 & -0.182 & 0.166 \\
\hline
\end{tabular}

alone explained between 88.5 and $95.1 \%$ of the variance in the respective variables, which increased to between 95.5 and $97.3 \%$ when including random variation between years and trees (Table S1). However, the large fraction of variance explained by the fixed effects resulted mainly from the pronounced differences in wood anatomy between species and wood types. When calculated separately for each species and wood type, the fraction of variance explained by the fixed effects decreased markedly to around $10 \%$ on average, with particularly low values for the latewood of ring-porous species (likely related to the higher measurement uncertainty driven by often small numbers of vessels present in narrow latewood rings). In the model for tree-ring width (TRW), in total $19.5 \%$ of the variance was explained for the fixed effects. This resulted mostly from the much lower betweenspecies variability in TRW, while explained within-species variance was comparable to the wood anatomical variables with on average $11.4 \%$ (Table S1). The explained variance in TRW increased to $90.6 \%$ when accounting for individualand year-specific random effects. Notably, after accounting for species, size and climate effects, individual variability and yearly random fluctuations, a highly significant residual autocorrelation signal was present in all models (AR1 autocorrelation parameters between 0.84 and 0.96 ; cf. Table S3).

\section{Species and stand differences in hydraulic architecture}

The five selected broad-leaved temperate tree species showed pronounced differences in several wood anatomical traits of the last ten growth rings, while differences between sites were relatively small (Fig. 3a-d, Table S2). For the diffuse-porous tree species, the relative vessel lumen area $\left(A_{\text {lumen }}\right)$, i.e. the lumen-to-sapwood-area ratio, ranged between $25.1 \pm 0.9 \%$ (mean $\pm \mathrm{SE}$ ) in $F$. sylvatica and $9.3 \pm 0.4 \%$ in A. pseudoplatanus, while large differences were observed between earlywood (EW) and latewood (LW) in the two ring-porous tree species (EW $36.1 \pm 0.7 \%$ vs. LW $5.8 \pm 0.5 \%$ for $F$. excelsior and EW $33.5 \pm 0.9 \%$ vs. LW $13.1 \pm 1.8 \%$ for $Q$. petraea; cf. Table S2). VD followed a similar pattern for the diffuse-porous tree species, ranging between $115.3 \pm 3.7 \mathrm{n} \mathrm{mm}^{-2}$ in $F$. sylvatica and $28.8 \pm 1.1$ $\mathrm{n} \mathrm{mm^{-2 }}$ in A. pseudoplatanus, while pronounced differences between EW and LW were only found for $Q$. petraea $\left(5.8 \pm 0.3 \mathrm{n} \mathrm{mm}^{-2}\right.$ and $76.3 \pm 5.7 \mathrm{n} \mathrm{mm}^{-2}$, respectively; cf. Table $\mathrm{S} 2$ ). $D_{\mathrm{h}}$ was relatively constant between the three diffuse-porous species and ranged between $63.7 \pm 1.3 \mu \mathrm{m}$ in $F$. sylvatica and $76.8 \pm 2.0 \mu \mathrm{m}$ in A. pseudoplatanus, but differed roughly fourfold among diffuse- and ring-porous species (Table S2). Even larger were the differences in potential conductivity $\left(K_{\mathrm{p}}, \mathrm{kg} \mathrm{m}^{-1} \mathrm{MPa}^{-1} \mathrm{~s}^{-1}\right)$ between diffuse- and ring-porous species (up to 30-fold; cf. Table S2). In contrast, the site differences in anatomical and hydraulic parameters typically ranged between 1 and $20 \%$ only and rarely reached $100 \%$. This result emphasizes the large functional diversity in hydraulic properties which can exist among different temperate tree species in the same stand. At least in our study, species differences in hydraulic properties were much larger than any site effects. Species differences in the growth-related variables tree-ring width (TRW) and basal area increment (BAI), on the other hand, were much lower, while there were indications for pronounced site differences in growth in several species (Fig. 3e, f; Table S2).

The grouping into species/wood types was the factor that explained the by far largest fraction of variance in all analyzed wood anatomical variables, both via large differences in their average value (compare scale in Fig. 3) and via highly significant differences in the response to nearly all other predictor variables in the model (cf. Table S3). This was specifically notable in the distinction between the earlyand latewood of ring-porous species, which differed strongly 

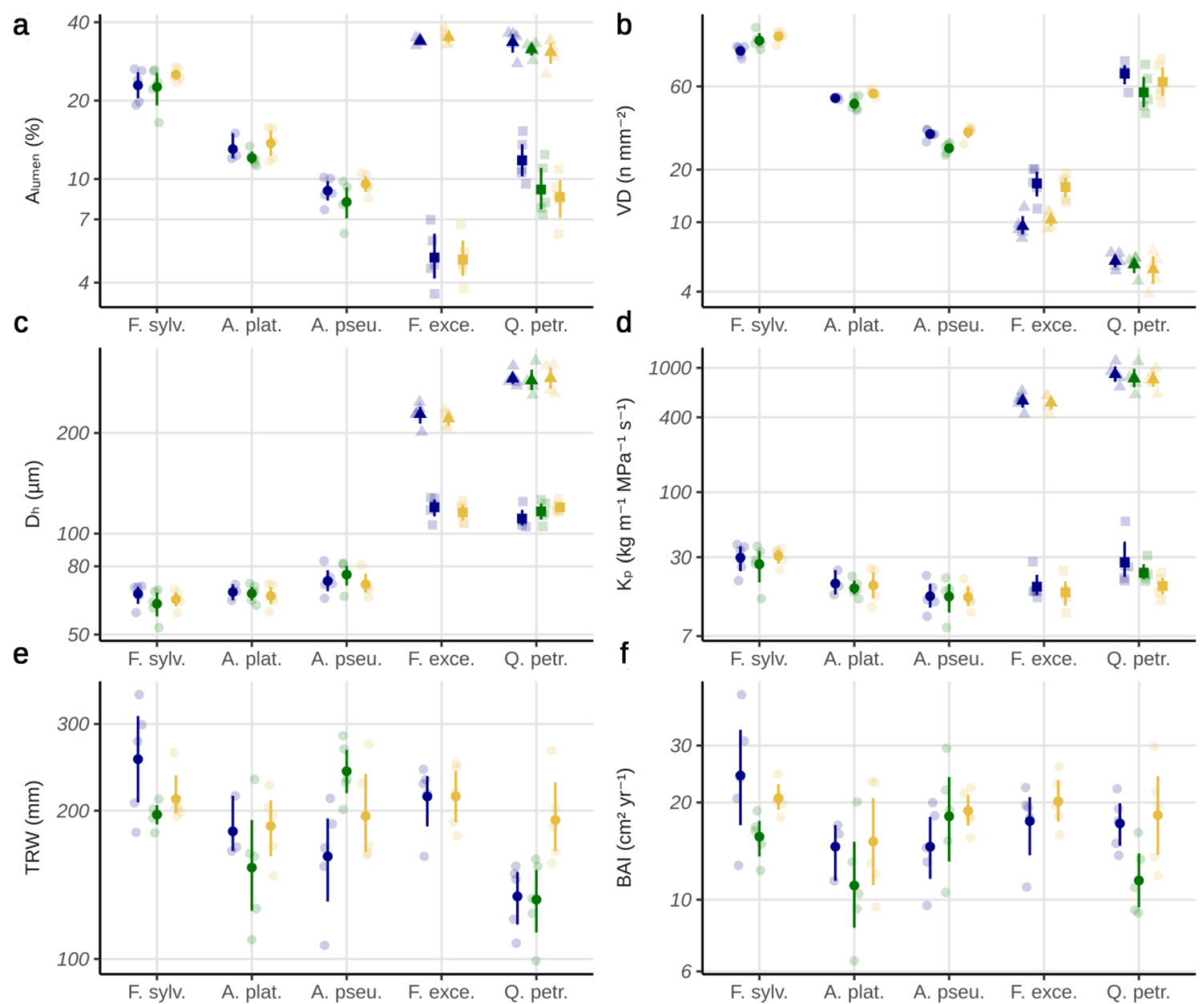

Stand 1

Stand 2

Stand 3

Fig. 3 Growth-related data as well as parameters characterizing the hydraulic system of the stem xylem in the five tree species in the three stands (see legend for colors). Given are the relative vessel lumen area $\left(A_{\text {lumen }}, \%\right)$, vessel density $\left(\mathrm{VD}, n \mathrm{~mm}^{-2}\right)$, hydraulicallyweighted vessel diameter $\left(D_{\mathrm{h}}, \mu \mathrm{m}\right)$, potential conductivity $\left(K_{\mathrm{p}}, \mathrm{kg}\right.$

within species in their average values, in the direction of climate responses and in error variances, effectively making it necessary to treat them as separate groups. In all fitted models, error variances differed highly significantly between species and wood types (Table S3). For the wood anatomical traits in the latewood of ring-porous species, this was exacerbated by the response of TRW to climatic variables, as the very narrow latewood ring widths in dry years resulted in lower vessel counts and hence less accurate estimates of $D_{\mathrm{h}}$, $\mathrm{VD}$ and $K_{\mathrm{p}}$. This is reflected in the lower explained variance and wider confidence bounds for parameter estimates of the corresponding species/wood types (cf. Figs. 4, 5; Table S3). $\mathrm{m}^{-1} \mathrm{MPa}^{-1} \mathrm{~s}^{-1}$ ), tree-ring width (TRW, mm) and basal area increment (BAI, $\mathrm{cm}^{2}$ year $^{-1}$ ). The shown data (cf. Table S2) are tree averages over the last ten years (2001-2010). Values are means with bootstrapped $95 \%$ confidence intervals $(n=1000)$ and are displayed on a $\log _{10}$-scale

\section{Interrelationships between wood anatomical and growth-related variables}

While $D_{\mathrm{h}}$ and VD were negatively associated for all diffuse-porous species (with the exception of $F$. sylvatica in Stand 1) and for the earlywood of ring-porous species, no correlation was discernible in the latewood of ring-porous species (Table 4, Fig. S1). Across all species and wood types, TRW was more closely related to VD than to $D_{\mathrm{h}}$, with higher vessel densities in narrower year rings across all species and wood types (Table 4, Fig. S1). In diffuseporous trees, $D_{\mathrm{h}}$ tended to show a contrasting pattern with 
a

\section{F. sylvatica \\ A. platanoides \\ A. pseudoplatanus \\ F. excelsior EW \\ F. excelsior $L W$ \\ Q. petraea $E W$ \\ Q. petraea $L W$}

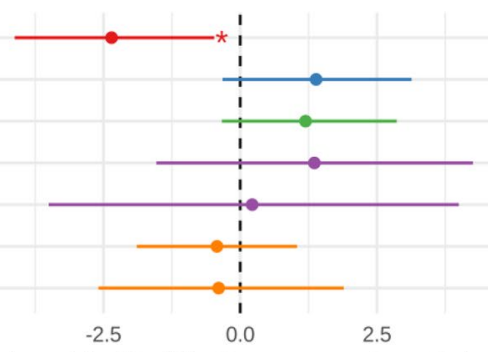

Long term trend in $\mathrm{Dh}_{\mathrm{h}}(\%$ change per decade)

b F. sylvatica

A. platanoides

A. pseudoplatanus

F. excelsior EW

F. excelsior LW

Q. petraea $E W$

Q. petraea $L W$

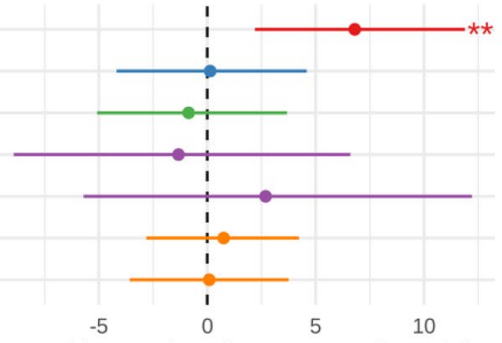

Long term trend in VD (\% change per decade)

C

F. sylvatica

A. platanoides

A. pseudoplatanus

F. excelsior EW

F. excelsior LW

Q. petraea $E W$

Q. petraea $L W$

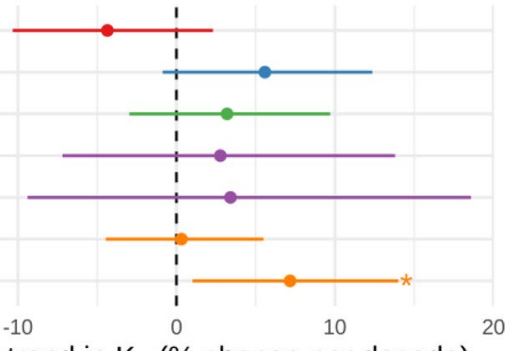

Long term trend in $\mathrm{K}_{\mathrm{p}}$ ( $\%$ change per decade)

\section{d}

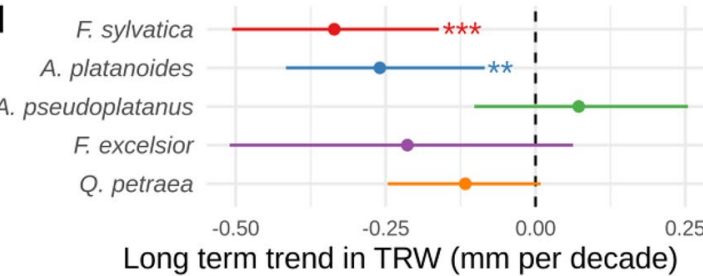

Fig. 4 Left: estimates of long-term changes in hydraulically weighted vessel diameter $\left(D_{\mathrm{h}}, \mu \mathrm{m} ; \mathbf{a}\right)$, vessel density $\left(\mathrm{VD}, n \mathrm{~mm}^{-2} ; \mathbf{b}\right)$, potential conductivity $\left(K_{\mathrm{p}}, \mathrm{kg} \mathrm{m}^{-1} \mathrm{MPa}^{-1} \mathrm{~s}^{-1} ; \mathbf{c}\right)$ and tree-ring width (TRW, mm; d) for the five species based on the linear mixed-effects model predictions after correcting for tree size effects and the effect of CWB (ring-porous species separated by wood type). Given are

larger vessels in wider annual rings, though this trend could not be detected at all sites (Table 4, Fig. S1). For the two ring-porous species, vessel diameters were largely independent of tree ring width, both in early- and latewood (Table 4, Fig. S1).

\section{Long-term and ontogenetic trends in stem wood hydraulic architecture and growth}

We found a significant increase in $D_{\mathrm{h}}$ with tree diameter for $F$. sylvatica and the earlywood of $Q$. petraea $(p<0.05$
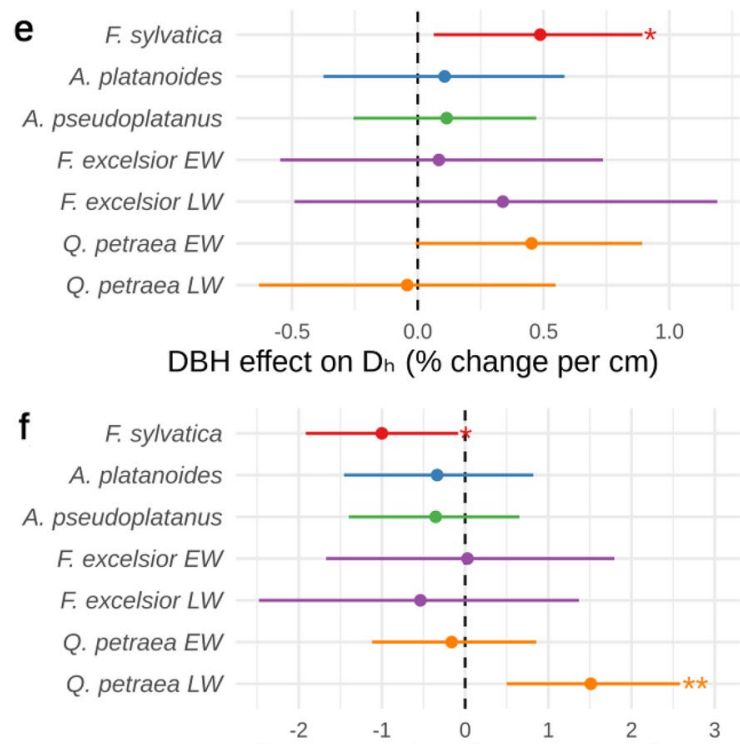

DBH effect on VD (\% change per $\mathrm{cm})$
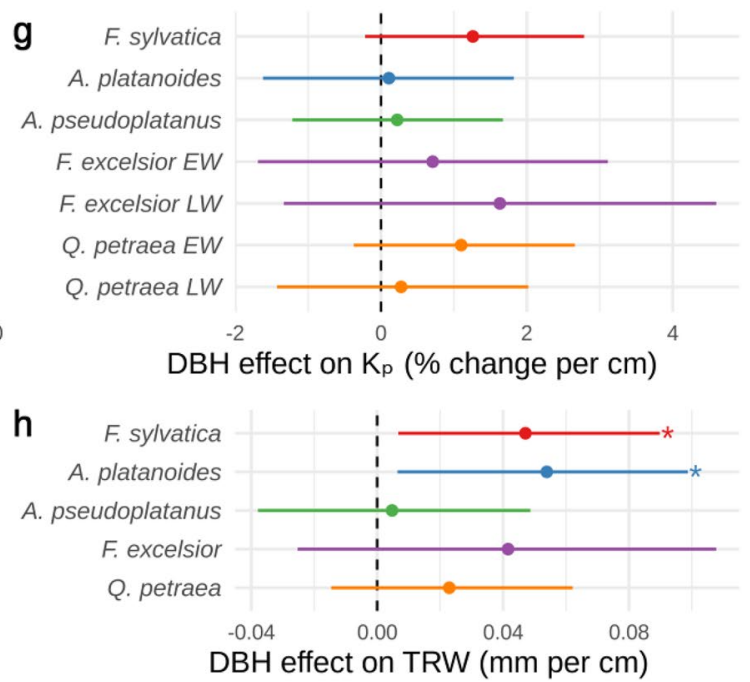

the estimated coefficients of linear trends with time including their 95\% bootstrap-based confidence intervals and approximate bootstrapped p-values based on 2500 parametric bootstrap samples. Right: estimates of size effects for the same variables as a change per $\mathrm{cm}$ increase in diameter $(\mathbf{e}-\mathbf{h})$. Stars indicate significance level $(* p<0.05 ; * * p<0.01 ; * * * p<0.001)$

based on 2,500 bootstrap samples; Table S3), while no significant trends were identified for the other species (Fig. 4e, Table S3). However, the variance parameter of the random slope for DBH indicates a large variation in the tree-specific response to tree diameter $(p<0.001$; Table S3). After accounting for species- and individualspecific ontogenetic trends with tree diameter, $D_{\mathrm{h}}$ did not change significantly with time for all species except for $F$. sylvatica, where a decline in $D_{\mathrm{h}}$ over the course of the study interval was clearly visible in the detrended raw data (Fig. S2). This is mirrored in the parameter estimates of 
a
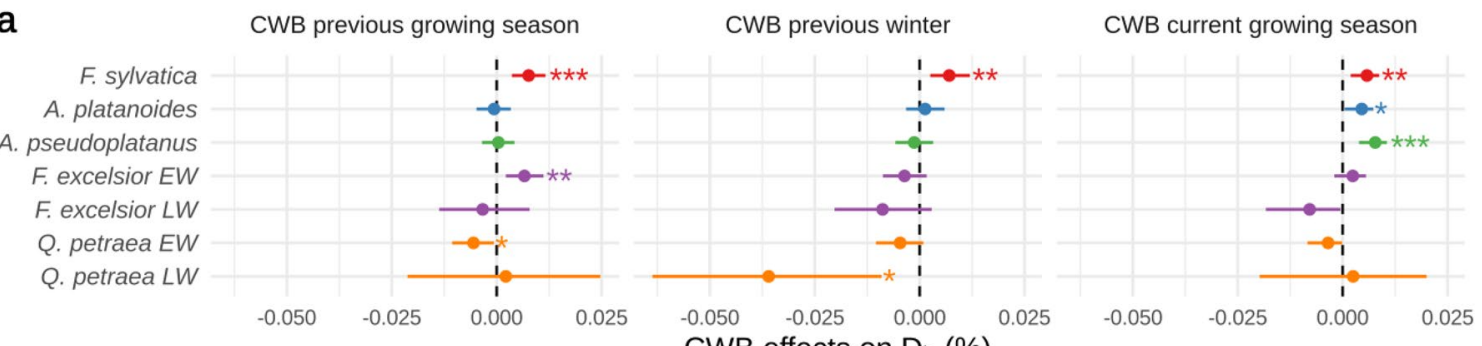

b

CWB previous growing season

CWB effects on $D_{h}(\%)$
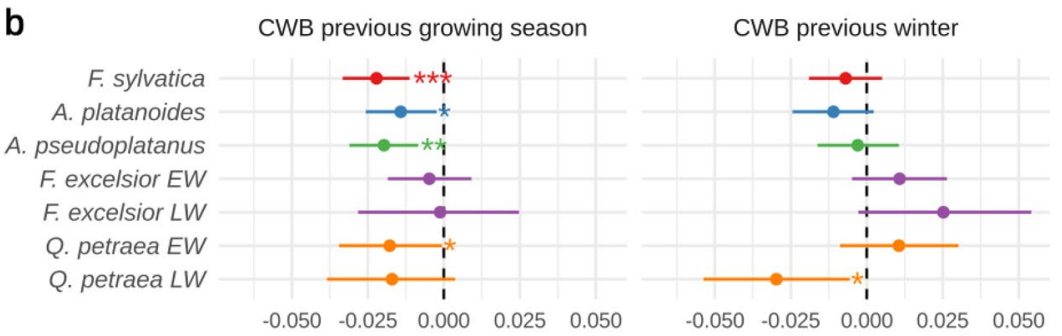

CWB current growing season

C

CWB previous growing season CWB effects on VD (\%)
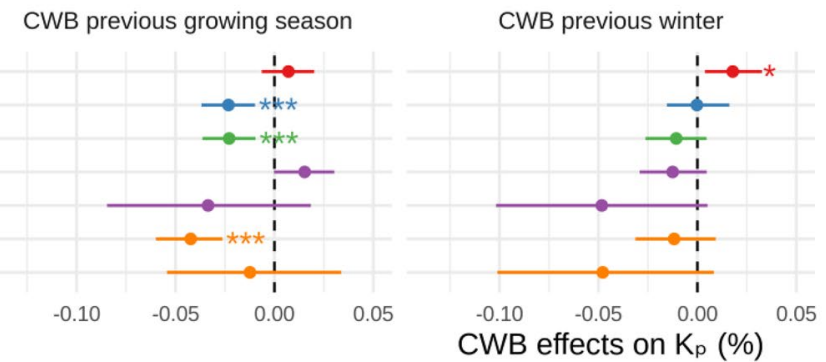

CWB current growing season

F. sylvatica
A. platanoides
A. pseudoplatanus
F. excelsior EW
F. excelsior $L W$
Q. petraea EW
Q. petraea $L W$

d

CWB previous growing season
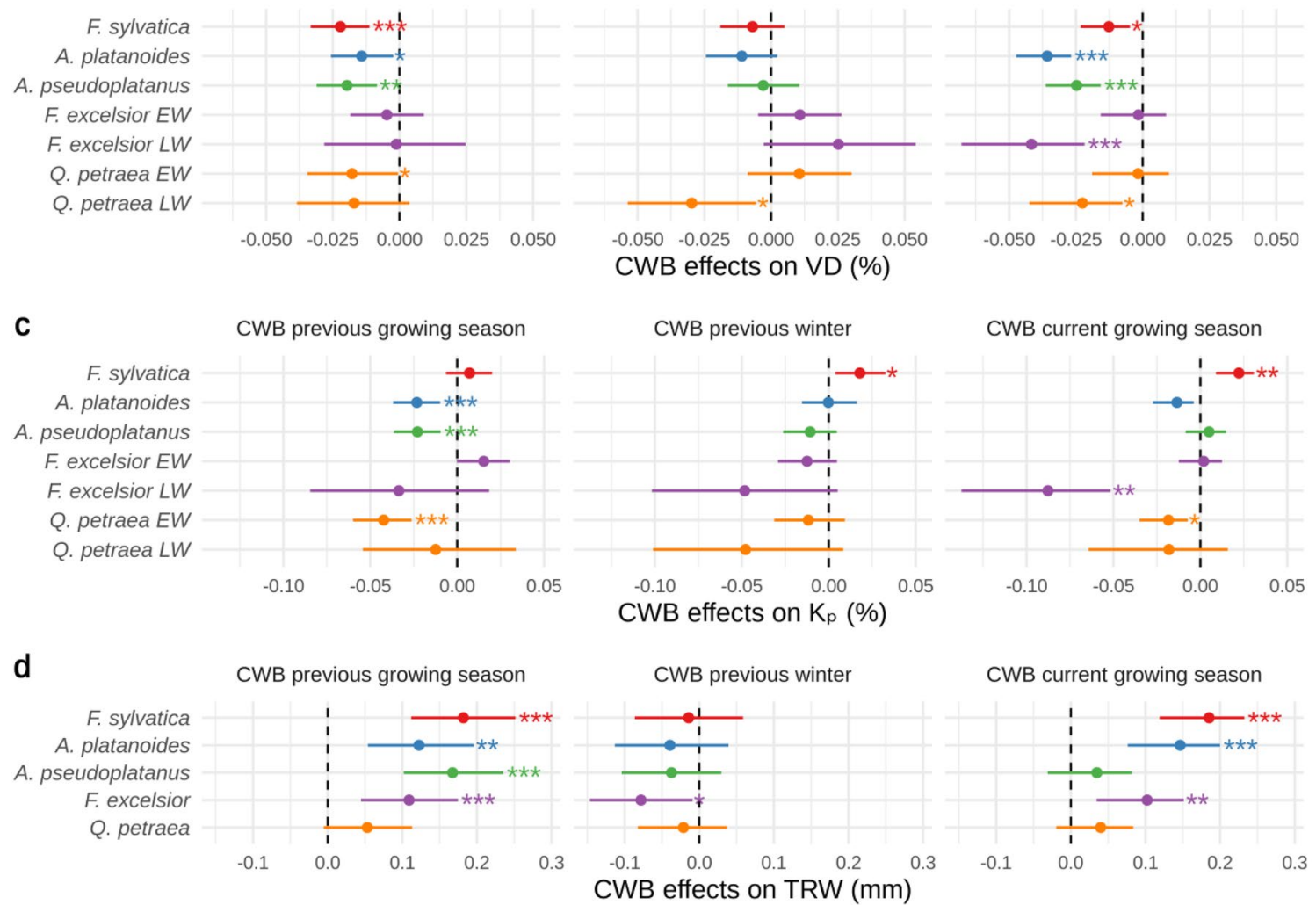

CWB current growing season

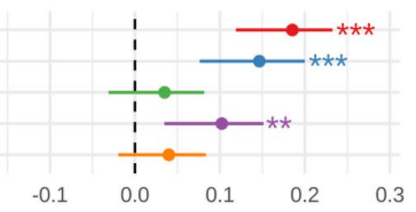

Fig. 5 Effect of the climatic water balance (CWB) on hydraulicallyweighted vessel diameter $\left(D_{\mathrm{h}}, \mu \mathrm{m}\right.$; a), vessel density (VD, $n \mathrm{~mm}^{-2}$; b), potential conductivity $\left(K_{\mathrm{p}}, \mathrm{kg} \mathrm{m}^{-1} \mathrm{MPa}^{-1} \mathrm{~s}^{-1}\right.$; c) and tree-ring width (TRW, mm; d) for the five species based on the linear mixedeffects model predictions (ring-porous species separated by wood type). Given are the relative effects of the CWB of the current and previous growing season as well as the previous winter (back-trans- formed and expressed as percent change per SD of CWB) including their 95\% bootstrap-based confidence intervals and approximate bootstrapped $p$ values based on 2500 parametric bootstrap samples. Stars indicate significance level $\left({ }^{*} p<0.05 ; * * p<0.01\right.$; $\left.* * * p<0.001\right)$. Positive effects indicate an increase in response to higher CWB values (i.e. less dry conditions)

VD decreased with tree diameter for $F$. sylvatica $(p<0.05)$, while it did not show any significant size effects for any other species, besides an increase in the latewood of $Q$. petraea $(p<0.01)$. While VD showed a much more pronounced response to short-term signals than $D_{\mathrm{h}}$ (cf. Fig. S2), there was no evidence for long term changes in VD for any of the species except for F. sylvatica significant (Fig. 4). 
Table 4 Pearson correlation coefficients for within-stand correlation between hydraulically weighted vessel diameter $\left(D_{\mathrm{h}}, \mu \mathrm{m}\right)$, vessel density $\left(V D, \mathrm{n} \mathrm{mm}^{-2}\right)$ and tree-ring width $(\mathrm{TRW}, \mathrm{mm})$

\begin{tabular}{|c|c|c|c|c|c|c|c|c|c|}
\hline \multirow[t]{2}{*}{ Species/woodtype } & \multicolumn{3}{|l|}{ Stand 1} & \multicolumn{3}{|l|}{ Stand 2} & \multicolumn{3}{|l|}{ Stand 3} \\
\hline & $D_{\mathrm{h}} \sim \mathrm{VD}$ & $\mathrm{TRW} \sim D_{\mathrm{h}}$ & TRW VD & $D_{\mathrm{h}} \sim \mathrm{VD}$ & $\mathrm{TRW} \sim D_{\mathrm{h}}$ & TRW VD & $D_{\mathrm{h}} \sim \mathrm{VD}$ & $\mathrm{TRW} \sim D_{\mathrm{h}}$ & TRW VD \\
\hline F. sylvatica & -0.166 & 0.411 & -0.655 & -0.386 & 0.206 & -0.661 & -0.648 & 0.393 & -0.641 \\
\hline A. platanoides & -0.273 & 0.275 & -0.638 & -0.596 & 0.428 & -0.665 & -0.257 & 0.048 & -0.446 \\
\hline A. pseudoplatanus & -0.538 & 0.445 & -0.417 & -0.417 & 0.493 & -0.651 & -0.615 & 0.037 & -0.554 \\
\hline F. excelsior EW & -0.766 & 0.216 & -0.479 & & & & -0.738 & 0.045 & -0.244 \\
\hline F. excelsior LW & 0.008 & 0.091 & -0.740 & & & & 0.124 & -0.013 & -0.769 \\
\hline Q. petraea $\mathrm{EW}$ & -0.442 & 0.099 & -0.366 & -0.651 & 0.082 & -0.173 & -0.652 & 0.040 & -0.454 \\
\hline Q. petraea LW & 0.027 & -0.067 & -0.438 & -0.149 & 0.086 & -0.388 & 0.004 & -0.016 & -0.232 \\
\hline
\end{tabular}

Types of correlations are specified in the sub-headers. For the ring-porous species (F. excelsior and $Q$. petraea), earlywood (EW) and latewood (LW) in each tree ring were treated separately

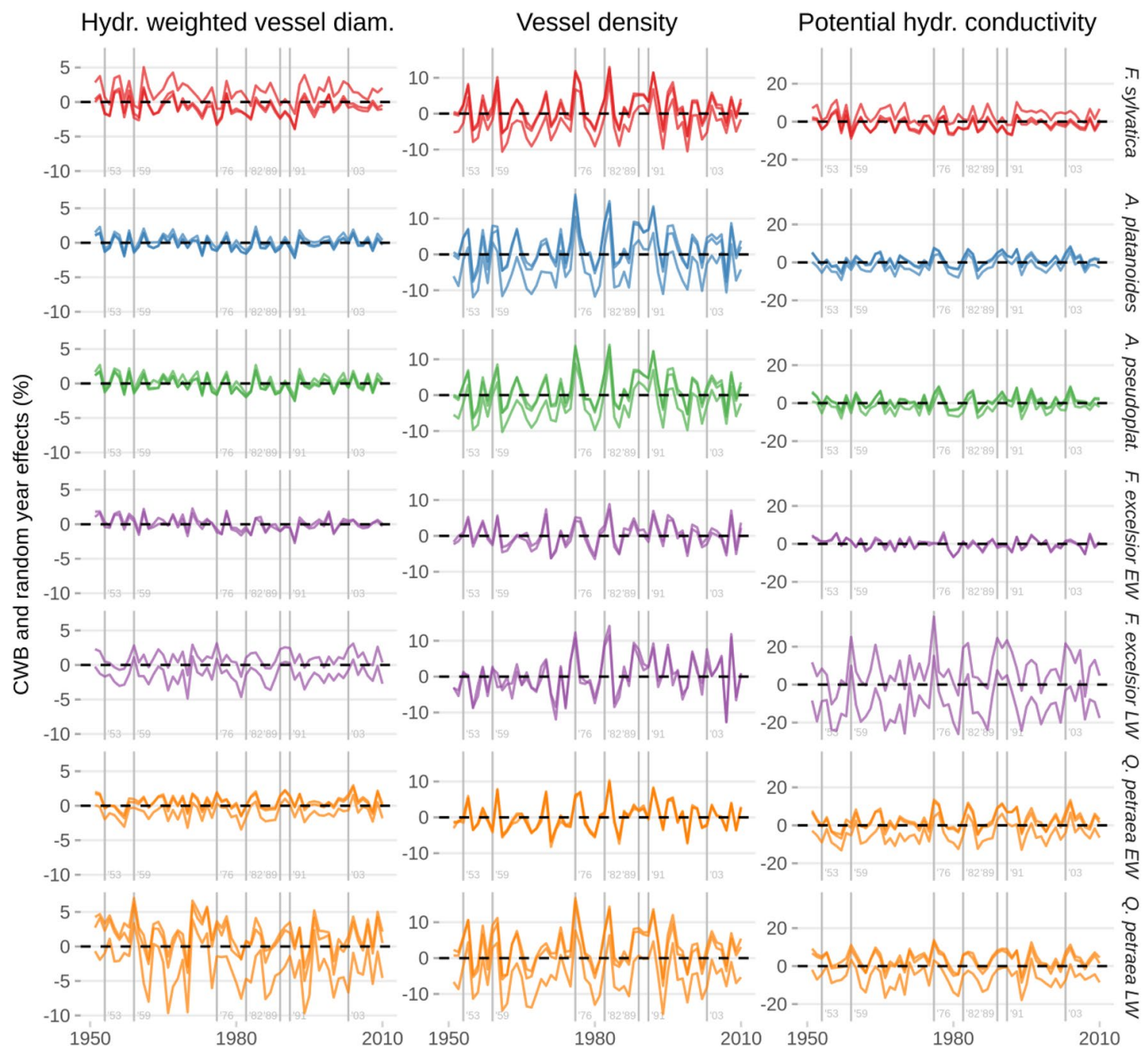

Fig. 6 Short-term changes in hydraulically weighted vessel diameter $\left(D_{\mathrm{h}}, \mu \mathrm{m}\right.$; left), and vessel density (VD, $n \mathrm{~mm}^{-2}$; middle), and in potential conductivity $\left(K_{\mathrm{p}} ; \mathrm{kg} \mathrm{m}^{-1} \mathrm{MPa}^{-1} \mathrm{~s}^{-1}\right.$; right $)$ for the five species based on the linear mixed-effects model predictions (ring-porous species were separated by wood type, i.e. early- and latewood). Given is how much each year differs from an 'average year' in percentage based on the combined effects of CWB in the current and previous growing season as well as the previous winter, plus random year effects 
$(p<0.01$; Fig. 4b, S2). For the latter species, the expected VD increased by $6.80 \%$ per decade over the course of the study interval. Notably, the pronounced long-term change in both $D_{\mathrm{h}}$ and VD of $F$. sylvatica was not accompanied by a significant change in $K_{\mathrm{p}}$, which did not show any significant long-term change except in the latewood of $Q$. petraea $(p<0.05$; Fig. 4c, S3). However, a tendency of declining TRW with time was present in all species except for A. pseudoplatanus (Fig. S4), and for both F. sylvatica and A. platanoides, the linear decline of TRW with time was highly significant ( $p<0.01$ in both cases; Fig. 4d).

\section{Climatic effects on wood production and vascular properties}

The response of the wood anatomical properties to changes in the CWB was highly species- and wood type-specific (Figs. 5, 6). Notably, F. sylvatica was the only species showing a significant decrease in $D_{\mathrm{h}}$ in response to a more negative CWB at all studied time lags, i.e. responding both to the current and previous growing season's CWB as well as the CWB of the previous winter $(p<0.01$ in all cases; Fig. 5a). In contrast, the other two diffuse-porous species, $A$. platanoides and A. pseudoplatanus, were both significantly influenced by the current year's CWB only $(p<0.05$ and $p<0.001$, respectively; Fig. 5a). The response of the $D_{\mathrm{h}}$ of ring-porous species to the CWB differed strongly between wood types, with a high uncertainty in the parameter estimates for the latewood driven by frequently observed small ring widths (Fig. 5a). The earlywood vessel diameter of $F$. excelsior was reduced in the years after growing seasons with low water availability $(p<0.01)$, while its latewood vessel diameter was marginally higher in dry years $(p<0.1$; Fig. 5a). Q. petraea unexpectedly increased its earlywood $D_{\mathrm{h}}$ in the years after dry summers $(p<0.01)$, while its latewood $D_{\mathrm{h}}$ was higher after dry winters $(p<0.001)$.

VD tended to respond more strongly to climate than $D_{\mathrm{h}}$ (cf. Fig. S2). Our model indicated increases of VD in the wood produced in years with dry growing periods as well as in the following years for all studied diffuse-porous species $(p<0.05$; Fig. 5b). For F. excelsior, earlywood vessel density was not affected by CWB, while latewood vessel density was increased in years with dry growing seasons $(p<0.001)$. In $Q$. petraea, the earlywood VD increased in the years after years with dry growing seasons $(p<0.05)$, while the VD of its latewood increased both in years with dry growing seasons and after dry winters ( $p<0.05$; Fig. 5b).

Notably, the stronger response of VD to a reduced CWB compared to $D_{\mathrm{h}}$ resulted in increases in $K_{\mathrm{p}}$ for at least some time lags and wood types for all species except for $F$. sylvatica. This species was the only one to suffer a significant reduction in $K_{\mathrm{p}}$ in response to low values of CWB $(p<0.01$; Fig. 5c). In either case, it is questionable how much the trees

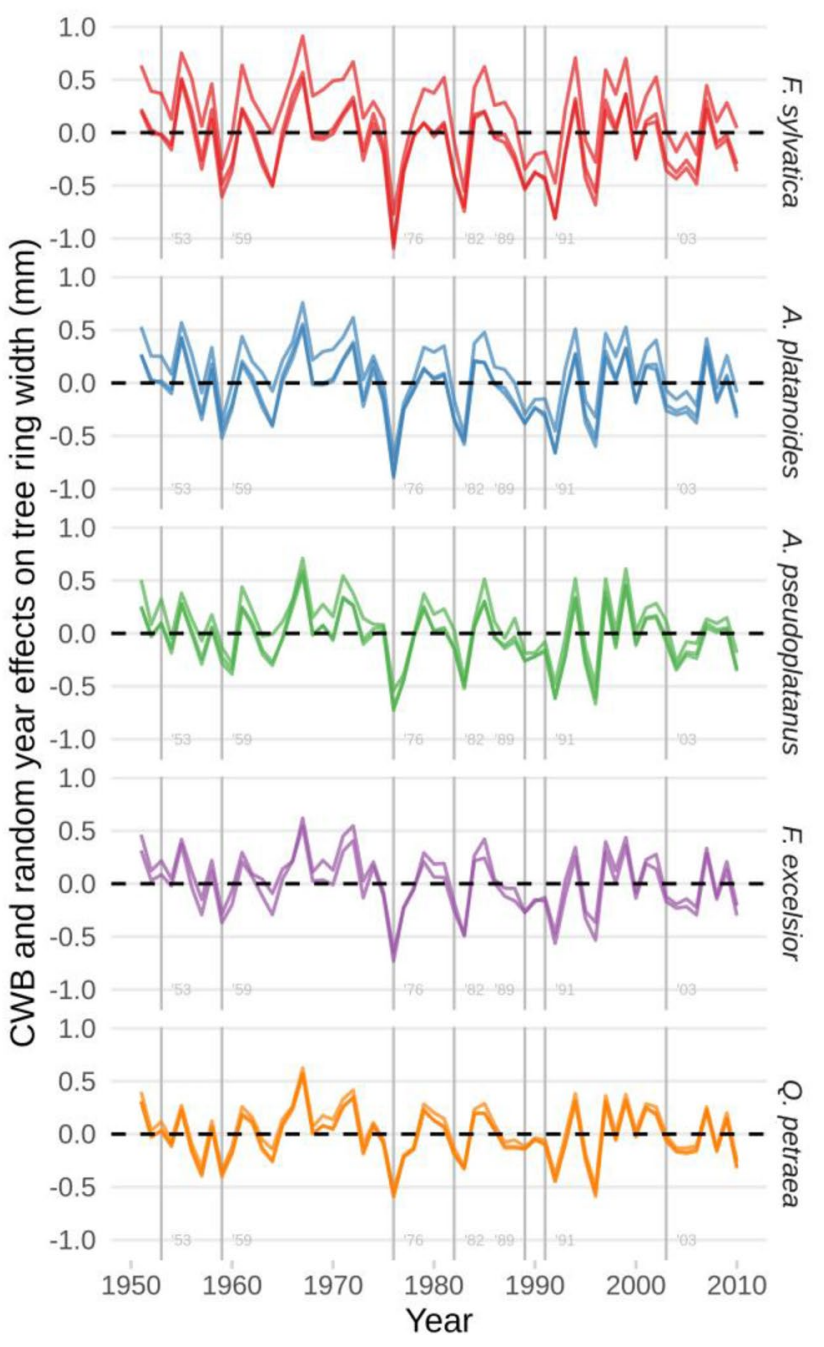

Fig. 7 Short-term changes in tree ring width (TRW; mm) for the five species based on the linear mixed-effects model predictions (ringporous species were separated by wood type, i.e. early- and latewood). Given is how much each year differs from an 'average year' in percentage based on the combined effects of CWB in the current and previous growing season as well as the previous winter, plus random year effects

benefitted from the increase in $K_{\mathrm{p}}$, as the observed changes in wood anatomy were accompanied by a decline of TRW with a low CWB $(p<0.001)$ for all species except for $Q$. petraea (Figs. 5d, 7).

\section{Discussion}

\section{Radial trends in stem wood anatomical properties}

In both gymnosperm and angiosperm trees, conduit size at the trunk base generally tends to increase with diameter growth, at least during the first years of life (Spicer and Gartner 2001; Christensen-Dalsgaard et al. 2008; 
Li et al. 2019). The trees of our sample were on average $105.0 \pm 2.6$ years old (mean $\pm \mathrm{SE}$ ), which means that we might have missed pronounced age effects on vessel dimensions by excluding the first $\sim 45$ years from our analysis. From the five trees species of our sample, only two showed a significant increase in vessel diameter by approximately $5 \%$ per $10 \mathrm{~cm}$ radial growth, namely $F$. sylvatica and $Q$. petraea. In general, trees respond to the higher water demand of an expanding crown, increasing flow resistances and a larger gravitational force when growing tall by increasing conduit diameters at the stem base (Lachenbruch et al. 2011). This increase in conduit size, especially during juvenile wood formation, is thought to be a function of cambial ageing (Gartner 1995; Kirfel et al. 2017; Li et al. 2019) and resulting changes in auxin concentration during vascular differentiation (Aloni 1987). While conduit size might increase constantly with age in some species, several studies observed that conduit size remained either constant or that the radial increase in conduit size slowed down after approximately 30 years, which agrees with our results (Leal et al. 2006, 2011; Fan et al. 2009).

According to our model, the vessel diameters of F. sylvatica were significantly larger and vessel density lower in larger trees in a given year, indicating significant ontogenetic changes in these variables. However, these ontogenetic trends were overlain by significant long-term changes in the opposite direction. As a consequence, newly formed wood in trees of a given diameter contained smaller vessels (reduction by $2.35 \%$ per decade) but at higher numbers (increase in vessel density by $6.80 \%$ per decade), which was accompanied by a constant decline in tree-ring width (see also Zimmermann et al. 2015). While our model allowed to separate these counteracting patterns, which are masked by the close dependence of DBH on time (see Methods section), there was a large uncertainty in the estimates obtained for all effects of time and DBH. This results from the high correlation between the two predictors of $\rho=0.69$ (Pearson correlation, notably under the conventional collinearity threshold of $\rho=0.7$; cf. Dormann et al., 2013), which results in correlated parameter estimates and ultimately wider confidence bounds for these parameters (cf. Fig. 4, Table S3).

In agreement with our second hypothesis, $F$. sylvatica was the only species showing a pronounced modification of its stem hydraulic system during the past decades, which confirms the anticipated drought-sensitivity of this species (e.g. Rennenberg et al. 2004; Leuschner 2009). On the other hand, our results might also be interpreted as evidence for a relatively high plasticity of the stem hydraulic system of this species, which is in agreement with former studies on branch hydraulic properties (Wortemann et al. 2011; Schuldt et al. 2016; Lübbe et al. 2017; Stojnic et al. 2018). Yet, it remains unclear whether a higher hydraulic plasticity and acclimation potential of $F$. sylvatica is sufficient to cope with a future increase in climatic aridity. After the 2018/2019 extreme drought, elevated mortality rates have been reported especially in stands with low soil-water holding capacity throughout Central Europe, which are a clear indicator of vulnerability (Schuldt et al. 2020).

\section{Climatic effects on xylem anatomical and derived hydraulic properties}

Studies with various tree species have demonstrated a direct effect of plant-available water on wood anatomical properties when different sites are compared. Decreasing water availability typically causes the formation of smaller xylem vessels and higher vessel densities (Carlquist 1977; Sterck et al. 2008; Chenlemuge et al. 2014; Pfautsch et al. 2016), but part of these observations might result from differences in tree size along the studied environmental gradients (Olson and Rosell 2013, Olson et al. 2014). A consequence of reduced vessel diameters is an increased resistance against drought-induced hydraulic failure, as it has been found in the gradient study of Schuldt et al. (2016) and the drought experiment of Lübbe et al. (2017). Our study results, in contrast, do only partly support the assumed strong relationship between water availability and corresponding xylem anatomy. Although we observed a distinct adjustment of anatomical properties to inter-annual change in climatic conditions, modifications in the hydraulic architecture across the precipitation gradient were less clear, and site effects were rarely significant in our models (cf. Table S3). Because we selected trees of comparable height and thus flow path length at all three sites, a lacking vessel-climate relationship comes not as a surprise (e.g. Lechthaler et al. 2019).

In contrast to the precipitation gradient study, our longterm wood anatomical time series revealed a strong influence of current year's climate on vessel diameter (diffuse-porous species only) and vessel density (diffuse-porous species and the latewood of ring-porous species) in agreement with our first hypothesis. A strong influence of spring or early summer precipitation on vessel diameter has been found for ring-porous Quercus species (García-González and Eckstein 2003; Fonti and García-González 2008) as well as for diffuse-porous $F$. sylvatica (Sass and Eckstein 1995; Schuldt et al. 2016). Accordingly, trees produce sapwood with less vessels but larger diameters in moist summers that allows supporting a larger leaf area and maintaining a more favourable leaf water status. For most species, these anatomical modifications are directly related to an increase in tree-ring width. Similar patterns have been observed by Corcuera et al. (2004), who observed the formation of narrow tree-rings characterized by small vessels during drought periods in Quercus ilex. In Q. petrea, however, we observed an increase, and not decrease, in earlywood vessel diameter in years following dry summers, and this species' tree-ring 
width was least affected by the previous year's cumulative water balance. Although this finding seems counterintuitive at first glance, the observed time-lag effect supports recent findings of drought recovery in oaks. For example, Anderegg et al. (2015) report strong positive legacy effects at dry oak sites, indicating that these ring-porous angiosperms are able to increase, and not decrease, stem growth after drought exposure. Due to the close positive relationship between tree ring-width and vessel diameter, our results are in line with these findings and confirm the speculation by Kannenberg et al. (2019). The authors assumed that it would be easier for ring-porous species to restore hydraulic functioning after drought exposure due to the formation of new and large earlywood vessels at the beginning of the following growing season.

In agreement with the observed long-term trends in $F$. sylvatica, this species was the only one additionally responding to the climatic conditions during the last winter and former growing season, and the only diffuse-porous species whose potential conductivity declined in response to dry conditions. As discussed above, this might either be indicative for the assumed marked drought-sensitivity of this species, or point toward a high degree of stem wood hydraulic plasticity (e.g. Schuldt et al. 2016). Because $F$. sylvatica showed severe drought symptoms and high mortality rates after the 2018/19 Central European drought event (Schuldt et al. 2020), the first assumption currently seems more likely. In agreement hereon, Walthert et al. (2020) recently described $F$. sylvatica as a drought vulnerable tree species, mostly because it still transpires high amounts of water despite pronounced levels of drought-induced embolism.

\section{Species differences in wood anatomy and contrasting strategies of diffuse- and ring-porous species}

A main selecting force during the evolution of the hydraulic systems of trees is hydraulic efficiency, i.e. the capacity for maximum water transport under conditions of ample moisture availability. Across the three diffuse-porous species of our sample, potential hydraulic conductivity $\left(K_{\mathrm{p}}\right)$ was surprisingly similar despite pronounced differences in the lumen-to-sapwood area ratio and vessel density. In contrast, $K_{\mathrm{p}}$ was up to 30 -times larger in the earlywood of the ringporous species. However, given that ring-porous species mainly use the youngest ring for water transport (Ellmore and Ewers 1986; Kitin and Funada 2016), the diffuse-porous species with much deeper sapwood can achieve a similarly large, or even higher, stem wood conductance if the number of hydroactive rings is sufficiently large. As a consequence, growth rates were comparable between diffuse- and ringporous species (22.4 versus $21.6 \mathrm{~cm}^{2}$ year ${ }^{-1}$, respectively). On the other hand, water storage in the stem as a means of buffering periods of drought stress in the tree canopy is of much greater relevance in diffuse- than ring-porous temperate tree species (Betsch et al. 2011; Köcher et al. 2012). In drought-sensitive diffuse-porous species such as $F$. sylvatica, reduced diameter growth in episodes of drought reduces $K_{\mathrm{p}}$ and thus canopy water supply. In the long-term, this will reduce stem water storage capacity and might eventually result in a downward spiral of reductions in hydraulic efficiency, supported foliage and productivity.

Our data highlight the fundamentally different hydraulic systems of diffuse- and ring-porous trees, which are most easily recognized by contrasting vessel diameters and have implications for growth processes and drought sensitivity. Yet, the functional consequences of these differences are not well understood (McCulloh et al. 2010). By restricting water transport mostly to the current-year growth ring, ringporous species accept the loss of functionality of their highly efficient vessels after drought- or frost-exposure. However, both physiological and dendrochronological studies have revealed a rather low drought sensitivity of the ring-porous species of our sample (e.g. Leuschner et al. 2001; Köcher et al. 2009; Scherrer et al. 2011; Härdtle et al. 2013). More research is needed to understand why ring-porous trees tolerate the loss of functionality of their large earlywood vessels but still achieve a sufficient degree of hydraulic safety and growth maintenance under drought exposure. One might speculate that the hydraulic efficiency of the latewood is sufficient to supply the canopy in late summer after earlywood vessels have been embolized. These might mainly be needed to restore hydraulic functioning of the canopy in spring and for foliage development. In agreement with this assumption, $K_{\mathrm{p}}$ was comparable between diffuse-porous species and the latewood of the ring-porous species (23.1 versus $28.9 \mathrm{~kg} \mathrm{~m}^{-1} \mathrm{MPa}^{-1} \mathrm{~s}^{-1}$, respectively).

\section{Evaluating the significance of radial vessel features for complementing tree-ring width data}

Despite recent developments in low-cost computerized image-analysis systems, studying radial vessel features remains labour-intensive. While some authors conclude that radial vessel features add more information to the climatic signal captured by tree-ring width data (Campelo et al. 2010; Novak et al. 2013; Rita et al. 2016), others do not see any benefit (Pourtahmasi et al. 2011; Oladi et al. 2014). According to our analysis, radial vessel features are sensitive to changes in water availability and their response indeed is in a similar order of magnitude as tree-ring width data. However, wood anatomical responses to the climatic water balance are species-specific, likely because similar adjustments to the hydraulic system can result from changes in different wood anatomical traits. This makes radial vessel features highly valuable for predicting changes in the 
hydraulic behaviour of co-existing tree species. In the scope of ongoing climate change, such data will gain increasing importance for quantifying the hydraulic plasticity of different species. Due to a large amount of labour needed, however, this type of studies is likely not suited to improve climate reconstructions, which preferably should be based on tree-ring width data only.

\section{Conclusions}

By combining dendrochronological time-series analysis with radial vessel features, we were able to reconstruct the development of the trees' stem hydraulic system over six decades and to search for climatic determinants of xylem properties. Our data show that radial vessel features are highly sensitive to changes in water availability and that their climate responses are in a similar order of magnitude as that of tree-ring width data. In contrast to the treering width data, however, different species-specific wood anatomical adjustments may result in the same hydraulic efficiency. In consequence, the time lag, magnitude and direction of the response of wood anatomical traits to climate was highly species-specific.

All diffuse-porous species suffered a decline in vessel diameter in dry years, accompanied by an increase in vessel density, followed by reduced growth in this and/or the subsequent year. However, the response of $F$. sylvatica strikingly differed from that of the other species. It was the only species with (a) significant long-term change in key anatomical traits, (b) reduced potential hydraulic conductivity in response to both dry vegetation periods and dry winters, and (c) a significant drought response of hydraulic vessel diameter over all studied time lags. In consequence, F. sylvatica showed both the largest long-term decrease in tree-ring width and the largest ring width reduction in and after dry years.

The comparison of five tree species with different drought sensitivity and ring- or diffuse-porous xylem anatomy revealed an impressive diversity in stem hydraulic properties of the co-existing species. Although $K_{\mathrm{p}}$ differed by an order of magnitude between diffuse- and ringporous species, it was surprisingly similar after excluding the ring-porous earlywood.

We conclude that long-term reconstruction of xylem anatomical and derived hydraulic properties can add substantially to the understanding of tree growth responses to a changing climate. A particularly promising approach for future tree hydraulics research would be to apply the methods outlined here to a larger set of ring- and diffuse-porous tree species to compare the drought response of these two functionally different tree groups in a systematic way.
Author contribution statement $\mathrm{Cl}, \mathrm{BS}$ and $\mathrm{MH}$ designed the study, JZ collected the field samples, performed all measurements and carried out a first analysis of the data, which was improved by RML who developed the final model, performed the statistical analysis and rewrote the results chapter. JZ, CL and BS wrote the first version of the manuscript, which was intensively discussed and revised by all authors.

Supplementary Information The online version contains supplementary material available at https://doi.org/10.1007/s00468-021-02090-2.

Acknowledgements We thank the Deutsche Bundesstiftung Umwelt (DBU) and the administration of the Biosphere Reserve Karstlandschaft-Südharz for allowing tree coring in their stands. We thank the German Weather Service (DWD, Deutscher Wetterdienst, Offenbach) for supplying climate data. We also like to thank Stefan Meyer (Göttingen) for his support during the stand selection phase of the project, and two anonymous reviewers who helped improving the manuscript.

Funding Open Access funding enabled and organized by Projekt DEAL. This research was funded by the DFG (Deutsche Forschungsgemeinschaft) within the project GRK 1086 "The role of biodiversity for biogeochemical cycles and biotic interactions in temperate deciduous forests", which is gratefully acknowledged.

Data accessibility All data used in this manuscript are present in the manuscript and its supporting information

Code availability The code will be made available upon request, please contact RML (roman.link@ plant-ecology.de).

\section{Compliance with ethical standards}

Conflict of interest The authors declare no competing interests.

Open Access This article is licensed under a Creative Commons Attribution 4.0 International License, which permits use, sharing, adaptation, distribution and reproduction in any medium or format, as long as you give appropriate credit to the original author(s) and the source, provide a link to the Creative Commons licence, and indicate if changes were made. The images or other third party material in this article are included in the article's Creative Commons licence, unless indicated otherwise in a credit line to the material. If material is not included in the article's Creative Commons licence and your intended use is not permitted by statutory regulation or exceeds the permitted use, you will need to obtain permission directly from the copyright holder. To view a copy of this licence, visit http://creativecommons.org/licenses/by/4.0/.

\section{References}

Allen CD, Macalady AK, Chenchouni H, Bachelet D, McDowell N, Vennetier M, Kitzberger T, Rigling A, Breshears DD, Hogg EH, Gonzalez P, Fensham R, Zhang Z, Castro J, Demidova N, Lim JH, Allard G, Running SW, Semerci A, Cobb N (2010) A global overview of drought and heat-induced tree mortality reveals emerging climate change risks for forests. For Ecol Manag 259:660-684

Aloni R (1987) Differentiation of vascular tissues. Annu Rev Plant Physiol Plant Mol Biol 38:179-204 
Allen RG, Pereira LS, Raes D, Smith M (1998) Crop Evapotranspiration: Guidelines for Computing Crop Water Requirements. FAO, Rome

Anderegg WRL, Meinzer FC (2015) Wood anatomy and plant hydraulics in a changing climate. In: Hacke U (ed) Functional and ecological xylem anatomy. Springer International Publishing, Cham, pp 235-253

Anderegg WRL, Schwalm C, Biondi F et al (2015) Pervasive drought legacies in forest ecosystems and their implications for carbon cycle models. Science 349:528-532. https://doi.org/10.1126/scien ce.aab1833

Bates D, Mächler M, Bolker B, Walker S (2015) Fitting Linear MixedEffects Models Using lme4. J Stat Softw 67:1-48. https://doi. org/10.18637/jss.v067.i0110.18637/jss.v067.i01.

Betsch P, Bonal D, Breda N, Montpied P, Peiffer M, Tuzet A, Granier A (2011) Drought effects on water relations in beech: the contribution of exchangeable water reservoirs. Agric For Meteorol 151:531-543

Bigler C, Bräker OU, Bugmann H, Dobbertin M, Rigling A (2006) Drought as an inciting mortality factor in scots pine stands of the Valais, Switzerland. Ecosystems 9:330-343

Boessenkool (2019) rdwd: select and download climate data from 'DWD' (German Weather Service). R package version 1.2.0. https ://CRAN.R-project.org/package $=$ rdwd

Bohn U, Neuhäusl R, with contributions by Gollub G, Hettwer C, Neuhäuslová Z, Raus T, Schlüter H, Weber H (2003) Map of the natural vegetation of Europe. Scale 1:2500000. Bundesamt für Naturschutz (BfN)/Federal Agency for Nature Conservation, Bonn

Bolte A, Czajkowski T, Kompa T (2007) The north-eastern distribution range of European beech a review. Forestry 80:413-429

Bréda N, Huc R, Granier A, Dreyer E (2006) Temperate forest trees and stands under severe drought: a review of ecophysiological responses, adaptation processes and long-term consequences. Ann For Sci 63:625-644

Brodribb TJ (2009) Xylem hydraulic physiology: the functional backbone of terrestrial plant productivity. Plant Sci 177:245-251

Brooks ME, Kristensen K, van Benthem KJ, Magnusson A, Berg CW, Nielsen A, Skaug HJ, Maechler M, Bolker BM (2017) glmmTMB balances speed and flexibility among packages for zero-inflated generalized linear mixed modeling. R J 9:378-400

Cailleret M, Jansen S, Robert EMR et al (2017) A synthesis of radial growth patterns preceding tree mortality. Glob Change Biol 23:1675-1690

Campelo F, Nabais C, Gutiérrez E et al (2010) Vessel features of Quercus ilex L. growing under Mediterranean climate have a better climatic signal than tree-ring width. Trees $24: 463-470$

Carlquist S (1977) Wood anatomy of Onagraceae-additional species and concepts. Ann Mo Bot Gard 64:627-637

Cavin L, Mountford EP, Peterken GF, Jump AS, Whitehead D (2013) Extreme drought alters competitive dominance within and between tree species in a mixed forest stand. Funct Ecol 27:1424-1435

Charru M, Seynave I, Morneau F, Bontemps JD (2010) Recent changes in forest productivity: an analysis of national forest inventory data for common beech (Fagus sylvatica L.) in northeastern France. For Ecol Manag 260:864-874

Chenlemuge T, Schuldt B, Dulamsuren C, Hertel D, Leuschner C, Hauck M (2014) Stem increment and hydraulic architecture of a boreal conifer (Larix sibirica) under contrasting macroclimates. Trees. https://doi.org/10.1007/s00468-014-1131-x

Christensen-Dalsgaard KK, Ennos AR, Fournier M (2008) Are radial changes in vascular anatomy mechanically induced or an ageing process? Evidence from observations on buttressed tree root systems. Trees 22:543-550
Corcuera L, Camarero JJ, Gil-Pelegrín E (2004) Effects of a severe drought on Quercus ilex radial growth and xylem anatomy. Trees - Structure and Function 18:83-92

De Micco V, Aronne G, Baas P (2008) Wood anatomy and hydraulic architecture of stems and twigs of some Mediterranean trees and shrubs along a mesic-xeric gradient. Trees Struct Funct 22:643-655

Dormann CF, Elith J, Bacher S, Buchmann C, Carl G, Carré G, Marquéz JRG, Gruber B, Lafourcade B, Leitão PJ et al (2013) Collinearity: a review of methods to deal with it and a simulation study evaluating their performance. Ecography 36:27-46

Dreyer E (1997) Photosynthesis and drought in forest trees. In: Rennenberg H, Eschrich W, Ziegler H (eds) Contributions to modern tree physiology. Backhuys Publishers, Kerkwerve, pp $215-238$

Dulamsuren C, Hauck M, Kopp G et al (2017) European beech responds to climate change with growth decline at lower, and growth increase at higher elevations in the center of its distribution range (SW Germany). Trees Struct Funct 31:673-686

Ellmore GS, Ewers FW (1986) Fluid flow in the outermost xylem increment of a ring-porous tree, Ulmus americana. Am J Bot 73:1771-1774

Fan ZX, Cao KF, Becker P (2009) Axial and radial variations in xylem anatomy of angiosperm and conifer trees in Yunnan, China. IAWA J 30:1-13

Fonti P, García-González I (2008) Earlywood vessel size of oak as a potential proxy for spring precipitation in mesic sites. J Biogeogr 35:2249-2257

Fonti P, Jansen S (2012) Xylem plasticity in response to climate. New Phytol 195:734-736

Fonti P, Arx G, García-González I, Eilmann B, Sass-Klaassen U, Gärtner H, Eckstein D (2010) Studying global change through investigation of the plastic responses of xylem anatomy in tree rings. New Phytol 185:42-53

Gartner B (1995) Patterns of xylem variation within a tree and their hydraulic and mechanical consequences. In: Gartner B (ed) Plant stems - physiology and functional morphology. Academic Press, San Diego, pp 125-149

Gärtner H, Nievergelt D (2010) The core-microtome: a new tool for surface preparation on cores and time series analysis of varying cell parameters. Dendrochronologia 28:85-92

Gleason SM, Butler DW, Ziemińska K, Waryszak P, Westoby M (2012) Stem xylem conductivity is key to plant water balance across Australian angiosperm species. Funct Ecol 26:343-352

Gleason SM, Butler DW, Waryszak P (2013) Shifts in leaf and stem hydraulic traits across aridity gradients in Eastern Australia. Int J Plant Sci 174:1292-1301

Gonzalez IG, Eckstein D (2003) Climatic signal of earlywood vessels of oak on a maritime site. Tree Physiol 23:497-504

Hajek P, Leuschner C, Hertel D, Delzon S, Schuldt B (2014) Trade-offs between xylem hydraulic properties, wood anatomy and yield in Populus. Tree Physiol 34:744-756

Härdtle W, Niemeyer T, Assmann T, Aulinger A, Fichtner A, Lang A, Leuschner C, Neuwirth B, Pfister L, Quante M, Ries C, Schuldt A, von Oheimb G (2013) Climatic responses of tree-ring width and $813 \mathrm{C}$ signatures of sessile oak (Quercus petraea Liebl.) on soils with contrasting water supply. Plant Ecol 214:1147-1156

Harris I, Jones PD, Osborn TJ, Lister DH (2014) Updated high-resolution grids of monthly climatic observations-the CRU TS3.10 dataset. Int J Climatol 34:623-642

Jump AS, Hunt JM, Penuelas J (2006) Rapid climate change-related growth decline at the southern range edge of Fagus sylvatica. Glob Change Biol 12:2163-2174

Kannenberg SA, Novick KA, Alexander MR, et al (2019) Linking drought legacy effects across scales: From leaves to tree rings 
to ecosystems. Glob Chang Biol 25:2978-2992. https://doi. org/10.1111/gcb.14710

Kirfel K, Leuschner C, Hertel D, Schuldt B (2017) Influence of root diameter and soil depth on the xylem anatomy of fine- to mediumsized roots of mature beech trees in the top- and subsoil. Front Plant Sci 8:1194

Kitin P, Funada R (2016) Earlywood vessels in ring-porous trees become functional for water transport after bud burst and before the maturation of the current-year leaves. IAWA J 37:315-331

Knutzen F, Dulamsuren C, Meier IC, Leuschner C (2017) Recent climate warming-related growth decline impairs European beech in the center of its distribution range. Ecosystems 20:1494-1511

Köcher P, Gebauer T, Horna V, Leuschner C (2009) Leaf water status and stem xylem flux in relation to soil drought in five temperate broad-leaved tree species with contrasting water use strategies. Ann For Sci 66:101

Köcher P, Horna V, Leuschner C (2012) Environmental control of daily stem growth patterns in five temperate broad-leaved tree species. Tree Physiol 32:1021-1032

Kotowska MM, Hertel D, Abou Rajab Y et al (2015) Patterns in hydraulic architecture from roots to branches in six tropical tree species from cacao agroforestry and their relation to wood density and stem growth. Front Plant Sci 6:191

Kramer K, Degen B, Buschbom J, Hickler T, Thuiller W, Sykes MT, Winter W (2010) Modelling exploration of the future of European beech (Fagus sylvatica L.) under climate change-range, abundance, genetic diversity and adaptive response. For Ecol Manag 259:2213-2222

Lachenbruch B, Moore J, Evans R (2011) Radial variation in wood structure and function in woody plants, and hypotheses for its occurrence. In: Meinzer FC, Lachenbruch B, Dawson TE (eds) Size and age-related changes in tree structure and function. Springer, Dordrecht, pp 121-164

Leal S, Sousa VB, Pereira H (2006) Radial variation of vessel size and distribution in cork oak wood (Quercus suber L.). Wood Sci Technol 41:339-350

Leal S, Sousa VB, Knapic S, Louzada JL, Pereira H (2011) Vessel size and number are contributors to define wood density in cork oak. Eur J For Res 130:1023-1029

Lechthaler S, Turnbull TL, Gelmini Y et al (2019) A standardization method to disentangle environmental information from axial trends of xylem anatomical traits. Tree Physiol 39:495-502

Leuschner C (2009) Die Trockenheitsempfindlichkeit der Rotbuche vor dem Hintergrund des prognostizierten Klimawandels. Jahrbuch der Akademie der Wissenschaften zu Göttingen. Walter de Gruyter, Berlin, pp 281-296

Leuschner C, Ellenberg H (2017) Ecology of Central European Forests. Springer Nature, Cham

Leuschner C, Backes K, Hertel D, Schipka F, Schmitt U, Terborg O, Runge M (2001) Drought responses at leaf, stem and fine root levels of competitive Fagus sylvatica L. and Quercus petraea (Matt.) Liebl. trees in dry and wet years. For Ecol Manag 149:33-46

Lewis AM, Boose ER (1995) Estimating flow rates through xylem conduits. Am J Bot 82:1112-1116

Li S, Li X, Link R et al (2019) Influence of cambial age and axial height on the spatial patterns of xylem traits in Catalpa bungei, a ring-porous tree species native to China. Forests 10:662

Lindner M, Maroschek M, Netherer S, Kremer A, Barbati A, GarciaGonzalo J, Seidl R, Delzon S, Corona P, Kolström M, Lexer M, Marchetti M (2010) Climate change impacts, adaptive capacity, and vulnerability of European forest ecosystems. For Ecol Manag 259:698-709

Lübbe T, Schuldt B, Leuschner C (2017) Acclimation of leaf water status and stem hydraulics to drought and tree neighbourhood: alternative strategies among the saplings of five temperate deciduous tree species. Tree Physiol 37:456-468

McCulloh KA, Sperry JS, Lachenbruch B, Meinzer FC, Reich PB, Voelker S (2010) Moving water well: comparing hydraulic efficiency in twigs and trunks of coniferous, ring-porous, and diffuseporous saplings from temperate and tropical forests. New Phytol 186:439-450

McDowell NG (2011) Mechanisms linking drought, hydraulics, carbon metabolism, and vegetation mortality. Plant Physiol 155:1051-1059

Nakagawa S, Schielzeth H (2013) A general and simple method for obtaining R 2 from generalized linear mixed-effects models (RB O'Hara, Ed.). Methods Ecol Evol 4:133-142

Novak K, de Luís M, Raventós J, Čufar K (2013) Climatic signals in tree-ring widths and wood structure of Pinus halepensis in contrasted environmental conditions. Trees Struct Funct 27:927-936

Oladi R, Bräuning A, Pourtahmasi K (2014) "Plastic" and "static" behavior of vessel-anatomical features in Oriental beech (Fagus orientalis Lipsky) in view of xylem hydraulic conductivity. Trees Struct Funct 28:493-502

Olson ME, Rosell JA (2013) Vessel diameter-stem diameter scaling across woody angiosperms and the ecological causes of xylem vessel diameter variation. New Phytol 197:1204-1213

Olson ME, Anfodillo T, Rosell JA et al (2014) Universal hydraulics of the flowering plants: vessel diameter scales with stem length across angiosperm lineages, habits and climates. Ecol Lett 17:988-997

Pfautsch S, Harbusch M, Wesolowski A et al (2016) Climate determines vascular traits in the ecologically diverse genus Eucalyptus. Ecol Lett 19:240-248

Piovesan G, Biondi F, Di Fillipo A, Maugeri M (2008) Drought-driven growth reduction in old beech (Fagus sylvatica L.) forests of the central Apennines, Italy. Glob Change Biol 14:1265-1281

Pourtahmasi K, Lotfiomran N, Bräuning A, Parsapajouh D (2011) Tree-ring width and vessel characteristics of oriental beech (Fagus orientalis) along an altitudinal gradient in the Caspian forests, northern Iran. IAWA J 32:461-473

R Core Team (2020) R: a language and environment for statistical computing. R Foundation for Statistical Computing, Vienna, Austria. https://www.R-project.org/

Rennenberg H, Seiler W, Matyssek R, Gessler A, Kreuzwieser J (2004) European beech (Fagus sylvatica $\mathrm{L}$.) —a forest tree without future in the south of Central Europe? Allgemeine Forst und Jagdzeitung 175:210-224

Rita A, Borghetti M, Todaro L, Saracino A (2016) Interpreting the climatic effects on xylem functional traits in two Mediterranean Oak species: the role of extreme climatic events. Front Plant Sci $7: 1-11$

Roloff A, Schütt P (2006) Enzyklopädie der Holzgewächse, Handbuch und Atlas der Dendrologie. Ecomed Biowissenschaften, Einbändige Sonderausgabe ersch. U.d.T.: Enzyklopädie der Sträucher Edn. Landsberg am Lech

Rose L, Leuschner C, Köckemann B, Buschmann H (2009) Are marginal beech (Fagus sylvatica L.) provenances a source for drought tolerant ecotypes? Eur J For Res 128:335-343

Samaniego L, Thober S, Kumar R et al (2018) Anthropogenic warming exacerbates European soil moisture droughts. Nat Clim Change 8:421-426

Sass U, Eckstein D (1995) The variability of vessel size in beech (Fagus sylvatica L.) and its ecophysiological interpretation. Trees 9:247-252

Sass-Klaassen U, Fonti P, Cherubini P et al (2016) A tree-centered approach to assess impacts of extreme climatic events on forests. Front Plant Sci 7:1-6 
Schär C, Vidale PL, Lüthi D, Frei C, Häberli C, Liniger MA, Appenzeller C (2004) The role of increasing temperature variability in European summer heatwaves. Nature 427:332-336

Scharnweber T, Manthey M, Criegee C, Bauwe A, Schröder A, Wilmking M (2011) Drought matters-declining precipitation influences growth of Fagus sylvatica L. and Quercus robur L. in north-eastern Germany. For Ecol Manag 262:947-961

Scherrer D, Bader KFB, Körner C (2011) Drought-sensitivity ranking of deciduous tree species based on thermal imaging of forest canopies. Agric For Meteorol 151:1632-1640

Schindler U (1951) Das Buchensterben; bisherige Veröffentlichungen und Auswertungen der staatlichen Unterlagen. Forstarchiv 22:109-119

Schreiber SG, Hacke UG, Hamann A (2015) Variation of xylem vessel diameters across a climate gradient: insight from a reciprocal transplant experiment with a widespread boreal tree. Funct Ecol 29:1392-1401

Schuldt B, Knutzen F, Delzon S, Jansen S, Müller-Haubold H, Burlett R, Clough Y, Leuschner C (2016) How adaptable is the hydraulic system of European beech in the face of climate change-related precipitation reduction? New Phytol 210:443-458

Schuldt B, Buras A, Arend M, Vitasse Y, Beierkuhnlein C, Damm A, Gharun M, Grams TEE, Hauck M, Hajek P et al (2020) A first assessment of the impact of the extreme 2018 summer drought on Central European forests. Basic Appl Ecol 45:86-103

Sperry JS, Saliendra NZ (1994) Intra- and inter-plant variation in xylem cavitation in Betula occidentalis. Plant Cell Environ $17: 1233-1241$

Spicer R, Gartner BL (2001) The effects of cambial age and position within the stem on specific conductivity in Douglas-fir (Pseudotsuga menziesii) sapwood. Trees Struct Funct 15:222-229

Sterck FJ, Zweifel R, Sass-Klaassen U, Chowdhury Q (2008) Persisting soil drought reduces leaf specific conductivity in Scots pine (Pinus sylvestris) and pubescent oak (Quercus pubescens). Tree Physiol 28:529-536

Stojnić S, Suchocka M, Benito-Garzón M et al (2018) Variation in xylem vulnerability to embolism in European beech from geographically marginal populations. Tree Physiol 38:173-185

Taylor BM, Parida B, Davies J (2018) cruts: interface to climatic research unit time-series version 3.21 Data. $\mathrm{R}$ package version 0.5. https://CRAN.R-project.org/package $=$ cruts
Timofeeva G, Treydte K, Bugmann H et al (2017) Long-term effects of drought on tree-ring growth and carbon isotope variability in Scots pine in a dry environment. Tree Physiol 37:1028-1041

Trenberth KE, Dai A, van der Schrier G et al (2014) Global warming and changes in drought. Nat Clim Change 4:17-22

Trugman AT, Detto M, Bartlett MK et al (2018) Tree carbon allocation explains forest drought-kill and recovery patterns. Ecol Lett 21:1552-1560

Tyree MT (2003) Hydraulic limits on tree performance: transpiration, carbon gain and growth of trees. Trees Struct Funct 17:95-100

Wagenhoff A, Wagenhoff E (1975) Verlauf und Auswirkungen des Buchenrindensterbens im Forstamt Bovenden in den Jahren von 1959 bis 1965 . Aus dem Walde 24:111-168

Walthert L, Ganthaler A, Mayr S, Saurera M , Waldner P, Walser M, Zweifel R, von Arx G (2020) From the comfort zone to crown dieback: sequence of physiological stress thresholds in mature European beech trees across progressive drought. Sci Total Environ (in press)

Wickham H, Averick M, Bryan J et al (2019) Welcome to the Tidyverse. J Open Source Softw 4:1686

Wortemann R, Herbette S, Barigah TS, Fumanal B, Alia R, Ducousso A, Gomoray D, Roeckel-Drevet P, Cochard H (2011) Genotypic variability and phenotypic plasticity of cavitation resistance in Fagus sylvatica L. across Europe. Tree Physiol 31:1175-1182

Zimmermann J, Hauck M, Dulamsuren C, Leuschner C (2015) Climate warming-related growth decline affects Fagus sylvatica, but not other broad-leaved tree species in Central European mixed forests. Ecosystems 18:560-572

Zscheischler J, Seneviratne SI (2017) Dependence of drivers affects risks associated with compound events. Sci Adv 3:e1700263

Publisher's Note Springer Nature remains neutral with regard to jurisdictional claims in published maps and institutional affiliations. 